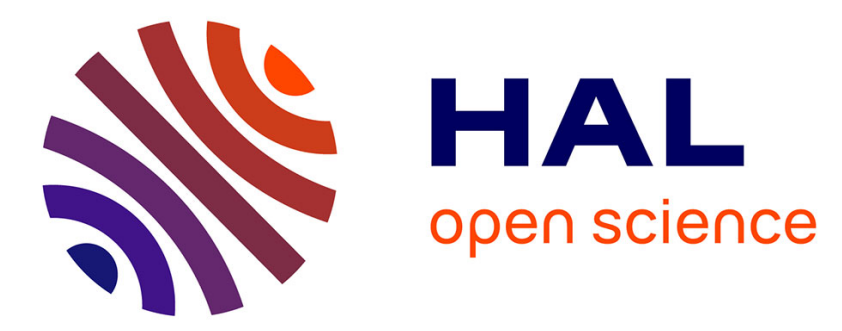

\title{
Variability of the South Atlantic upper ocean circulation: a data assimilation experiment with 5 years of Topex/Poseidon altimeter observations
}

Elodie Garnier, Jacques Verron, Bernard Barnier

\section{- To cite this version:}

Elodie Garnier, Jacques Verron, Bernard Barnier. Variability of the South Atlantic upper ocean circulation: a data assimilation experiment with 5 years of Topex/Poseidon altimeter observations. International Journal of Remote Sensing, 2003, 24 (5), pp.911-934. 10.1080/01431160210154902 . hal-00182964

\section{HAL Id: hal-00182964 \\ https://hal.science/hal-00182964}

Submitted on 13 Jan 2020

HAL is a multi-disciplinary open access archive for the deposit and dissemination of scientific research documents, whether they are published or not. The documents may come from teaching and research institutions in France or abroad, or from public or private research centers.
L'archive ouverte pluridisciplinaire HAL, est destinée au dépôt et à la diffusion de documents scientifiques de niveau recherche, publiés ou non, émanant des établissements d'enseignement et de recherche français ou étrangers, des laboratoires publics ou privés.

\section{(c)(1)}

Distributed under a Creative Commons Attribution| 4.0 International License 


\title{
Variability of the South Atlantic upper ocean circulation: a data assimilation experiment with 5 years of TOPEX/POSEIDON altimeter observations
}

\author{
E. GARNIER, J. VERRON and B. BARNIER \\ LEGI, UMR 5519 CNRS, BP 53X, 38041 Grenoble Cedex, France
}

\begin{abstract}
Dynamical interpolation of five years of TOPEX/POSEIDON alti-meter data (October 1992-September 1997) is performed in the South Atlantic basin, through the use of a simple quasigeostrophic model and a simple nudging data assimilation technique. The resulting data set is analysed in order to evidence the role of mesoscale eddies on the interannual variability of the South Atlantic ocean circulations. The annual mean circulations and the eddy fields reveal some significant interannual variability in the Brazil-Malvinas confluence region and in the Aghulas Retroflection region. But this interannual variability spreads out also in large extensions of those previous regions as well as in other areas of the South Atlantic basin. In particular, significant variability shows up in the upper return branch of the subtropical gyre that is interpreted in relation with the drift of some Aghulas rings. The role of those latter rings which are crucial for the Indian-Atlantic interocean exchange processes, is further investigated in the paper, and the fate of five specific rings analysed in detail. The overall influence of topography on the circulation is clearly evidenced, especially through its interaction with eddies.
\end{abstract}

\section{Introduction}

Prior to the intensive observation program carried out by the World Ocean Circulation Experiment (WOCE), the knowledge of the mean circulation in the South Atlantic was best summarized by the flow schematics of Peterson and Stramma (1991) for the surface ocean, and by the geostrophic analysis of Reid (1989) for the deeper ocean. At present, the analysis of the data collected during WOCE has already provided new insights into the mean circulation of water masses within the tropical and mid-latitude South Atlantic (Stramma and England 1999), and it is likely that the synthesis of the WOCE field program will finally provide a consistent picture of the mean general circulation in this basin.

The situation is quite different as far as variability is concerned. Evidence for an intense variability at eddy, seasonal and interannual time scales has been clearly established for some time in the region of the confluence between the Brazil and the Malvinas Currents (e.g. Olson et al. 1988, Podesta et al. 1991, Provost et al. 1992, Matano et al. 1993), and in the region of the Agulhas Current retroflection (e.g. Lutjerharms and van Ballegooyen 1988). Many observations collected during WOCE, and in particular the altimeter observations of TOPEX/POSEIDON (T/P), 
show the importance of the variability in these regions of the ocean (for example $\mathrm{Fu}$ 1996, Gründlingh 1995, Goni 1997, Matano et al. 1998). There is also from this altimeter data set some indication for interannual variability at the scale of the subtropical gyre (Witter and Gordon 1999). Evidence for interannual to interdecadal variability has also been found in monthly sea surface temperature and sea level pressure by Venegas et al. (1996). Nevertheless, the total amount of observations does not allow any comprehensive description of the interannual variability in this region of the world ocean, and information on the subject remains piecewise.

However, it is well established that mesoscale eddies generated in the two key regions of the South Atlantic that are the Confluence and the Agulhas Retroflection regions are extremely energetic. The way those eddies influence the large scale circulation is generally understood in terms of turbulent mixing: near surface water masses from different origins (Indian and Pacific Oceans) are transformed in these regions of intense turbulence before they eventually contribute to the upper branch of the global overturning cell which flows into the North Atlantic.

However, the contribution of the eddies to the mean circulation is certainly not limited to that mixing effect. It has been shown that eddy-topography interactions can drive significant mean circulation patterns, and the Zapiola Ridge Anticyclone (Saunders and King 1995, De Miranda et al. 1999) with a transport larger than $100 \mathrm{~Sv}$ is one striking example. The contribution of the mesoscale eddies to the interannual variability is even less documented, and is, together with the topographic influence, the subject of the present paper.

A $\frac{10}{6}$, four layered, quasi-geostrophic model is used to interpolate dynamically with a simple nudging technique, five years of $\mathrm{T} / \mathrm{P}$ data (from October 1992 to September 1997). The simulation produces a five year long data set of the model layer streamfunctions on a regular $\frac{1}{6}^{\circ}$ horizontal grid. This data set, sampled every three days, is analysed in an attempt to establish a possible link between the mesoscale eddies and the interannual variability of the circulation in the South Atlantic.

The paper is organized as follows. In $\S 2$, we briefly present the model used in our study, together with the assimilation technique and the altimeter data. The mean surface circulation obtained from the 5-year experiment is shortly discussed in $\$ 3$. Results on the interannual variability of both the mean circulation and the mesoscale activity are presented in $\$ 4$. Then we investigate several aspects of the behaviour of the Agulhas eddies during the observed period (§5). Finally, concluding remarks are given in $\S 6$.

\section{Method}

The model used in this study is the quasi-geostrophic model extensively described in Florenchie and Verron (1998). For purpose of clarity, we briefly recall here its main characteristics and configuration over the South Atlantic. The governing equations are the classical quasi-geostrophic (QG) equations (Pedlosky 1979), where the streamfunction $\psi_{k}$ and the relative vorticity $\Delta \psi_{k}$ are solved on the $\beta$-plane for each layer $k$. The dissipation process is ensured by the use of a Laplacian lateral viscosity operator $A \Delta^{2} \psi_{k}$. To take into account the bottom friction, we add a dissipative term $C \Delta \psi_{N}$ in the bottom layer $N$. In the experiments, the values of $A$ and $C$ are $200 \mathrm{~m}^{2} \mathrm{~s}^{-1}$ and $10^{-7} \mathrm{~s}^{-1}$ respectively.

The stratification profile is modelled by a four-layer representation, with layer thickness of 300, 300, 600 and $3800 \mathrm{~m}$ from surface to bottom. Our domain of interest is the South Atlantic extending between $16^{\circ} \mathrm{S}$ and $65^{\circ} \mathrm{S}$. The horizontal grid mesh is $\frac{1}{6}$ in latitude and longitude, implying a constant resolution of $18.5 \mathrm{~km}$ in latitude, 
and a variable grid step in longitude ranging from $17.8 \mathrm{~km}$ at the northern boundary to $7.8 \mathrm{~km}$ at the southern boundary.

The model coastlines, actually following the 200-m isobath, are taken into account with a capacitance matrix method (Blayo and Le Provost 1993). We use a no-slip boundary condition along these coastlines. Our model has three open boundaries: the northern limit at $16^{\circ} \mathrm{S}$; along $68^{\circ} \mathrm{W}$ in Drake Passage and along $32^{\circ} \mathrm{E}$. The boundary at $65^{\circ} \mathrm{S}$ is closed and considered as a coastline. At the open boundaries, we prescribe climatological transports in each layer, following Florenchie and Verron (1998) (see their figure 2). The open boundary condition is a combination of the radiation condition proposed by Raymond and Kuo (1984) and a relaxation toward an a priori known climatology (see Blayo et al. 1994).

The model is forced at the surface by the annual mean wind stress computed by Hellerman and Rosenstein (1983). Bottom topography is fully accounted for and acts in the bottom layer by means of a body force. The topographic data comes from the Synbaps-II database.

In our assimilation experiment, altimeter data from the T/P Geophysical Data Records (GDR) were used for the period October 1992-October 1997. The alongtrack mean sea-surface height $h$ was directly assimilated in the model, since in a QG multi-layered model, $h$ is related to the surface streamfunction $\psi_{1}$ by $h=f_{0} / g \cdot \psi_{1}$. Actually, the inaccuracies in the geoid correction lead us to assimilate a composite dynamic height $h=\bar{h}+h^{\prime}$, where $h^{\prime}$ is the altimeter residual with reference to a time mean sea-surface height (MSSH), $\bar{h}$, given by the model. Our first guess for the model MSSH $\left(\bar{h}_{0}\right)$ comes from the 2-year assimilation experiment of Florenchie and Verron (1998). Following the procedure of the previous authors, we assimilate the sea-surface height $h_{0}=\bar{h}_{0}+h^{\prime}$, and we compute the time average of the model result, $\bar{h}_{1}$, over the period covered by the data set. $\bar{h}_{1}$ differs from $\bar{h}_{0}$ because of the altimeter data and the model dynamics. This process is then iterated: we compute and assimilate $h_{n}=\bar{h}_{n}+h^{\prime}$ over the same period as previously, and obtain a new time average of the model results $\bar{h}_{n+1}$. A good convergence of the results is obtained after four successive iterations of the 5-year experiment.

As for the assimilation technique, the simple sequential, along-track nudging method was used (Verron and Holland 1989). It consists of adding to the surface streamfunction equation of evolution, a relaxation term of the form $R\left(\psi_{1}-\psi_{\text {obs }}\right)$, at the nearest grid points to the observations. Here $\psi_{o b s}$ is the observed surface streamfunction (proportional to the sea-surface height) which has been linearly interpolated between values corresponding to two successive satellite passages at a given location and at times $t_{\text {prev }}$ and $t_{\text {next }}$. The relaxation coefficient $R$ is written in the form $R=$ $R_{0} \exp \left(-\min \left(t-t_{\text {prev }}, t_{\text {next }}-t\right) / \tau\right)$ in order to maximize the strength of the constraint during the satellite passages and to minimize it between two successive passages. The coefficient $R_{0}$ is constant and determined empirically on the basis of previous experiments (Verron 1992). Its value is here $10^{-14} \mathrm{~m}^{-2} \mathrm{~s}^{-1}$. The timescale parameter $\tau$ measures the persistence of the nudging. It is set here at five days which is half the $\mathrm{T} / \mathrm{P}$ repeat time-scale: this ensures a smooth continuity of the assimilation process in time. This quite simple, and low cost, method was used in other assimilation experiments (Blayo et al. 1994, Florenchie and Verron 1998) and was found effective in constraining model circulation with altimeter data.

\section{General mean circulation}

The knowledge of the model mean circulation is a prerequisite for our study since it is strongly influenced by the variability generated by the altimeter data and 
by the non-linear processes taken into account in the model. Moreover, this prognosed mean circulation may be considered as a validation of the assimilation experiment. The 5-year mean surface stream function obtained from our model is shown in figure 1 . The mean surface circulation compares well with that obtained from the 2-year assimilation experiment of Florenchie and Verron (1998), both qualitatively and quantitatively (see their figure 3), so it will not be extensively described in the present paper which focuses on variability. The main features of the general circulation such as the Brazil-Malvinas Confluence (CONF), the Agulhas and Benguela Currents (AC, BEC), the Subtropical Gyre, the Subtropical Front (STF) and the frontal structures of the Antarctic Circumpolar Current (Polar Front $(\mathrm{PF})$ and Subantarctic Front (SAF)) are reproduced with a lot of realism (see Florenchie and Verron (1998) for details and justifications). Quasi-geostrophic are in principle inadequate to describe thermohaline frontal structures accurately. The correctness of our representation of the oceanic fronts should be mainly attributable to the residual altimeter data but shows up also partly in the free model, thus proving the extensiveness and robustness of the quasigeostrophic framework.

Figure 2 shows a sketch of these surface circulations in the South Atlantic ocean with indications of the circulation various features. In addition, figure 3 provides for the names and locations of the principal topographic features that are relevant to our study and mentioned in the following text.

The Subtropical Gyre spreads between approximately $22^{\circ} \mathrm{S}$ and $41^{\circ} \mathrm{S}$, from the American coast to about $10^{\circ} \mathrm{E}$. It has the expected assymmetrical shape, with weak and diffuse currents in its eastern limb and an intensified western boundary current (the Brazil Current (BC)). Whereas velocities in the gyre are only a few centimetres per second, we note the presence of zonal jets in the northern part of the gyre, with maximum velocities between 10 and $15 \mathrm{~cm} \mathrm{~s}^{-1}$ in the upper layer. As noticed by Florenchie and Verron (1998), such realistic front-like structures are not observed in a free-mode experiment (i.e. without data assimilation), and therefore are the result of the altimeter data assimilation.

These zonal flows feed and intensify the model Brazil Current which already

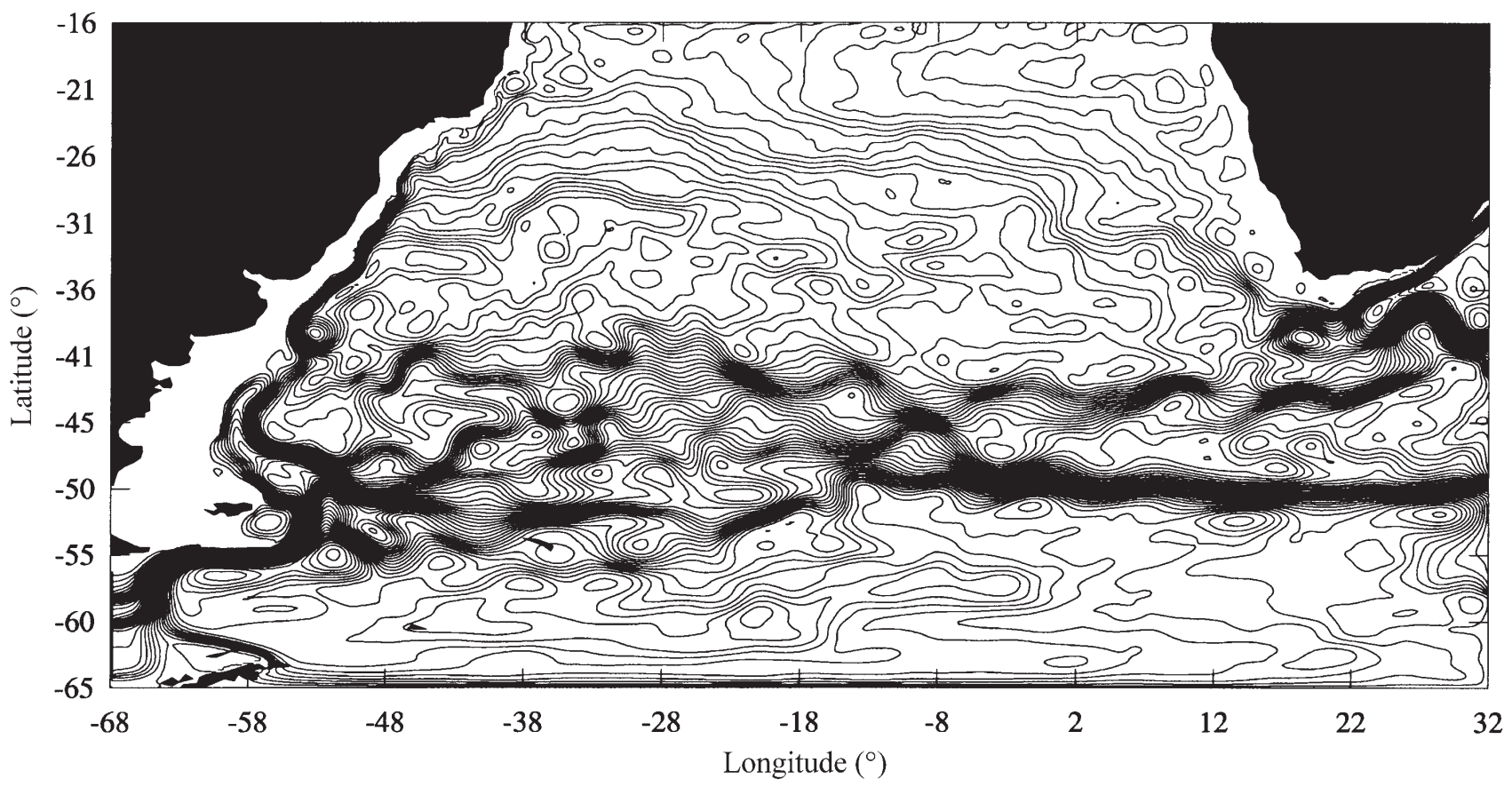

Figure 1. Mean stream function in the upper $300 \mathrm{~m}$ of the South Atlantic ocean circulation from the experiment (contour interval is $1 \mathrm{~Sv}$ ). 


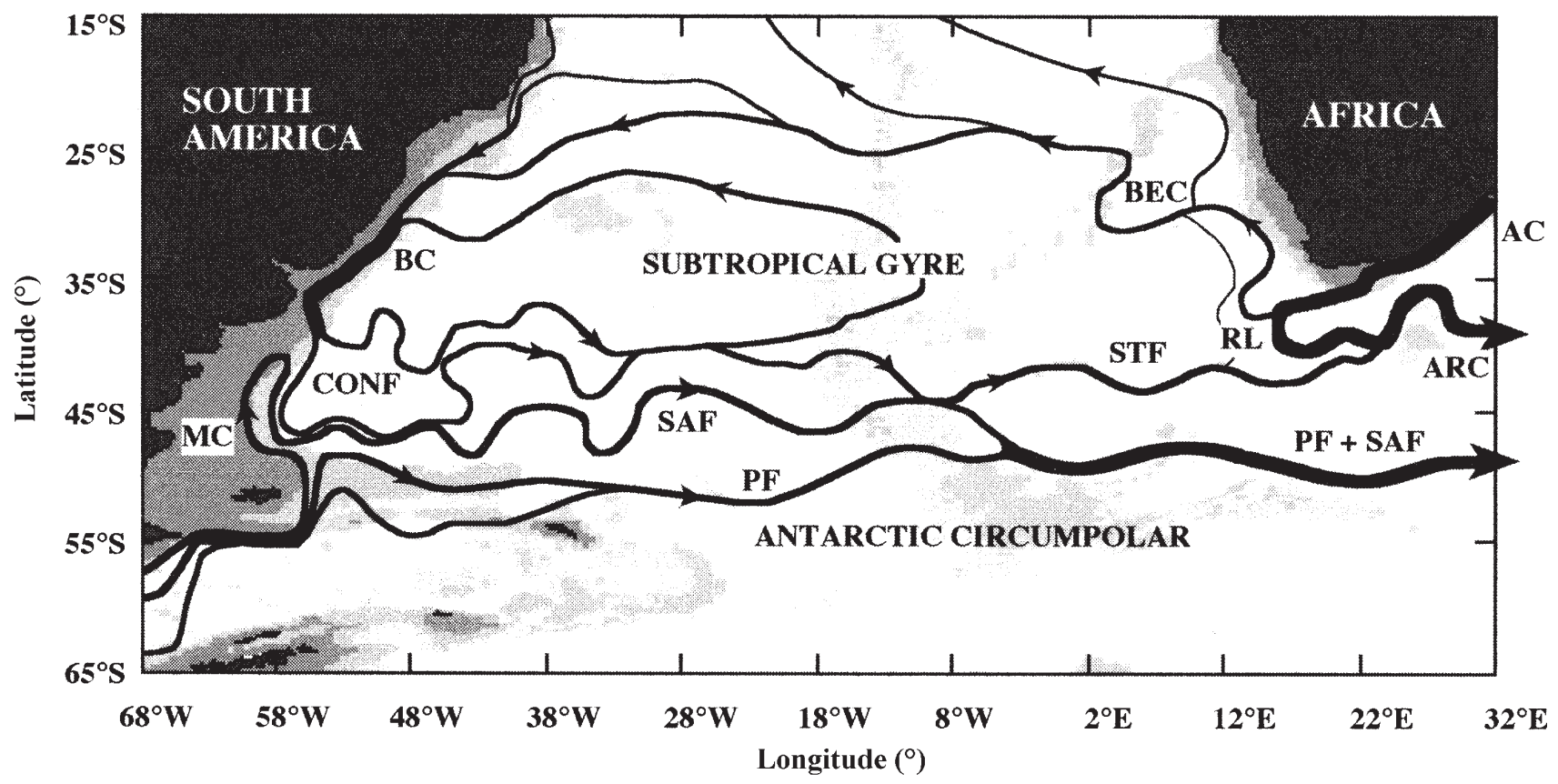

Figure 2. Sketch of the South Atlantic surface mean circulations: abbreviated terms are, BC, Brazil Current; MC, Malvinas Current; CONF, Confluence of the Brazil and Malvinas currents; AC, Agulhas Current; ARC, Agulhas Retroflection; PF, Polar Front; SAF, Subantarctic Front; STF, Subtropical Front; BEC, Benguela Current and Retroflection loop (RL).

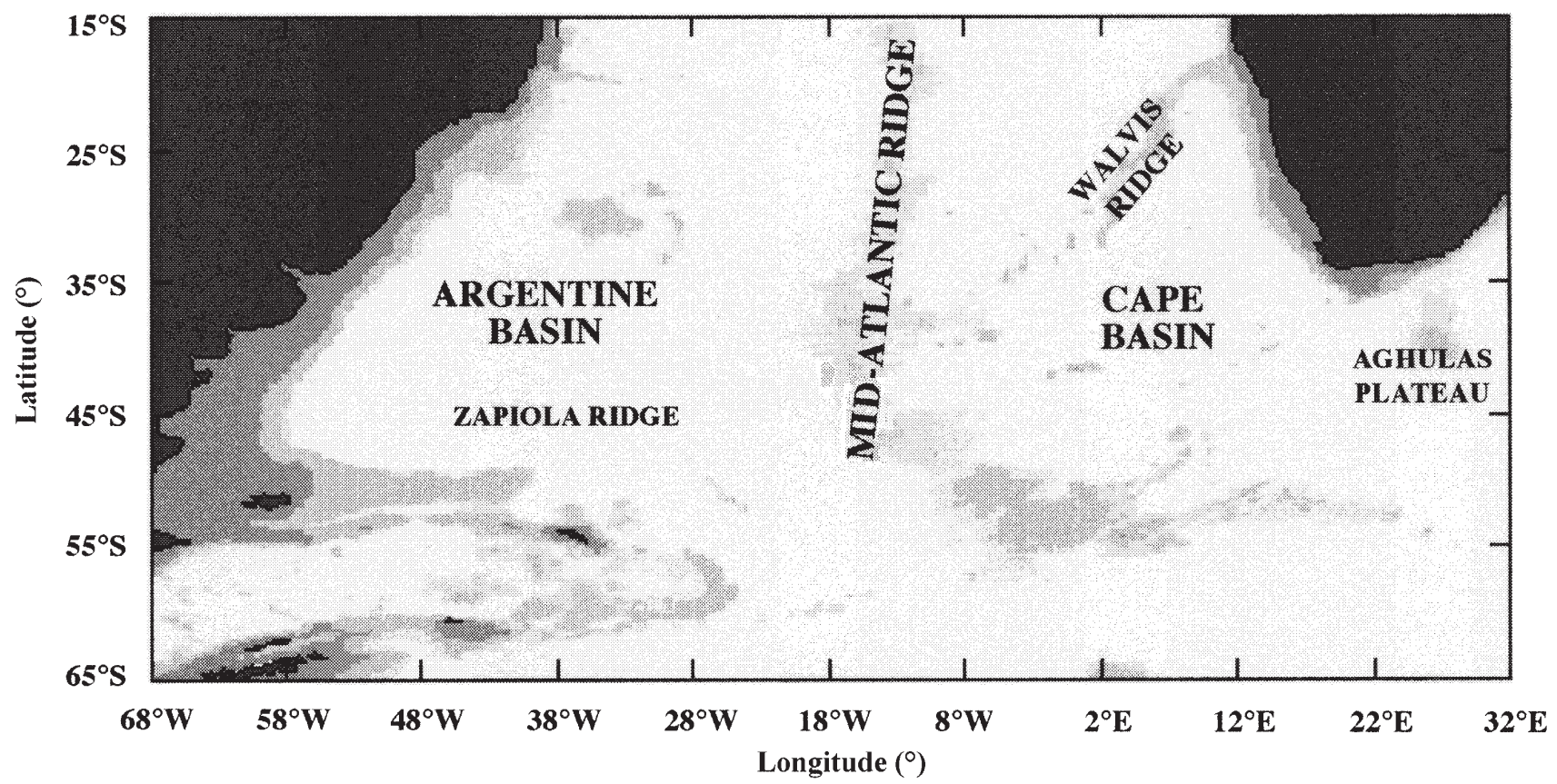

Figure 3. Sketch of the South Atlantic bathymetry with indications of the name locations of the main topographic features that are mentioned in the text.

appears as a jet-like structure at $28^{\circ} \mathrm{S}$. This current flows to the south-west along the American continent, and the maximum mean current speed reaches $70 \mathrm{~cm} \mathrm{~s}^{-1}$ in the surface layer at nearly $39^{\circ} \mathrm{S}$. At this latitude, the current is characterized by a strong recirculating eddy included into a broader but tight recirculation cell which extends up to $32^{\circ} \mathrm{S}$ (see also figure 10 of Florenchie and Verron 1998). This cell has also been described in Campos et al. (1995). After its separation from the coast, the Brazil Current splits into two branches. One branch flows eastward at about $42^{\circ} \mathrm{S}$ and forms the southern limb of the Subtropical Gyre. Another branch flows southwestward, as the so-called Confluence Front (Gordon and Greengrove 1986), joins 
the Malvinas Return Current near $43^{\circ} \mathrm{S}$, and then turns eastward and follows the Antarctic Circumpolar Current.

There is a clear signature of the Zapiola Anticyclone at $45^{\circ} \mathrm{S}-45^{\circ} \mathrm{W}$, a strong barotropic circulation feature related to a peculiar topographic feature in the Argentine Basin, only recently observed by Saunders and King (1995). A theoretical study by Dewar (1998) suggested that such a circulation would be driven by an eddy flux of potential vorticity in a region of closed $f / h$ contours. This hypothesis was later confirmed by De Miranda et al. (1999) who succeeded in reproducing this anticyclonic circulation pattern in a realistic fashion in a $\frac{1}{3}^{\circ}$ primitive equation model of the South Atlantic. But at present, most eddy resolving numerical model simulations have been unable to provide any reasonable evidence for this circulation, generally due to a poor representation of the eddy topographic stress. The Zapiola Anticyclone is typically a realistic mean flow structure introduced by the assimilation, since it is not seen in the free-mode (no assimilation) experiment. This pattern likely appears from the interaction between the bottom topography and the eddy flux of potential vorticity induced by the assimilation of the altimetric observations which contain the eddy variability peculiar to the Confluence region.

In the eastern part of the domain (see figure 2), the Agulhas Retroflection system $(\mathrm{ARC})$ is also reproduced with some realism. Originating from the Southern Indian Ocean, the model Agulhas Current (AC) flows southwestward along the coast of South Africa in a jet-like structure. Maximum velocities associated with the current reach about $130 \mathrm{~cm} \mathrm{~s}^{-1}$ at the surface, in good agreement with Pearce (1977). The model current separates from the continental shelf near $21^{\circ} \mathrm{E}$, in agreement with the analysis of Lutjeharms and van Ballegooyen (1988), based on satellite infrared imagery. Part of the current retroflects and flows back into the Indian Ocean as the Agulhas Return Current. This current is accelerated in the vicinity of the Agulhas plateau and flows around the topography, forming a large quasi-permanent cyclonic meander. When an Agulhas ring is to be shed from the Retroflection loop (RL), we observe a westward shift of the loop, often as far as $10^{\circ} \mathrm{E}$. Therefore, the eddy-like flow pattern centred at about $19^{\circ} \mathrm{E}-39^{\circ} \mathrm{S}$ in figure 1 actually corresponds to the mean position of the loop just before occurence of ring shedding. Indeed, this region is subject to very high variability (as will be seen below), and the position of the retroflection loop varies between $10^{\circ} \mathrm{E}$ and $22^{\circ} \mathrm{E}$. Part of the model Agulhas Current does not retroflect and enters the Benguela Current (BEC) of the South Atlantic with maximum velocities of about 15 to $20 \mathrm{~cm} \mathrm{~s}^{-1}$.

\section{Interannual variability}

Many features of the ocean circulation exhibit variability over a large range of timescales. In this section, we investigate the interannual variability of the circulation and mostly of its mesoscale variability as produced by our 5-year assimilation experiment.

\subsection{Annual mean circulation}

This study is not well-designed to analyse all components of the interannual variability of the South Atlantic mean circulations. The model is forced by climatological winds and quasi-geostrophy lacks of thermodynamics and steric effects. However eddy activity is prominent all over the basin and is well accounted for, both in the model and from the data: it is therefore a key feature of the variability of the mean circulations that are looked for here. 
As an attempt to get some indications on the overall behaviour of the model over the period, we have represented in figure 4 the annual mean sea-level anomalies averaged over the domain. A linear regression indicates that the model mean sealevel increases by $1.4 \mathrm{~mm} \mathrm{y}^{-1}$. This is consistent with estimations of the global sealevel trends ranging between 1 and $2 \mathrm{~mm} \mathrm{y}^{-1}$ (Gornitz 1995). In addition to this increase trend, we observe some interannual variability of the sea-level, with low sea-level in 1994 and high sea-level in 1996. Such a result cannot be interpreted at this stage and comparisons with other studies should be made.

The interannual variability contained in our experiment may be assessed by the standard deviation of the annual mean anomalies of the upper-layer ciculation, presented in figure 5. As expected, the regions of highest variability are the Brazil Current and the Agulhas Retroflection, where Rms values exceed $9 \mathrm{~Sv}$.

In the Brazil Current region, the area of highest interannual variability (larger than $5 \mathrm{~Sv} \mathrm{Rms}$ ) spreads over most of the northern Argentine basin, from $35^{\circ} \mathrm{S}$ to $43^{\circ} \mathrm{S}$ and far off the Rio de la Plata to about $40^{\circ} \mathrm{W}$. The highest level of variability corresponds roughly to the mean position of the recirculation cell of the Brazil

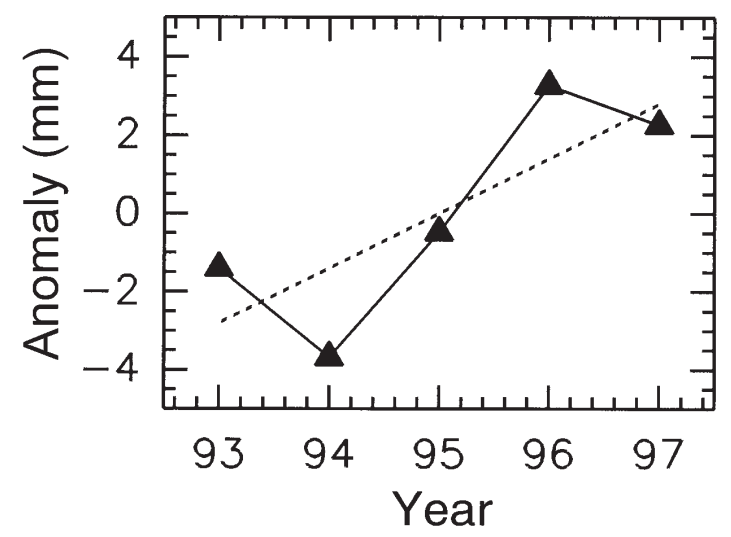

Figure 4. Annual mean sea-level anomalies, averaged over the domain for the 5-year experiment. The best-fit straight line (dotted) gives a global mean sea-level increase of $1.4 \mathrm{~mm}_{\text {year }}{ }^{-1}$.

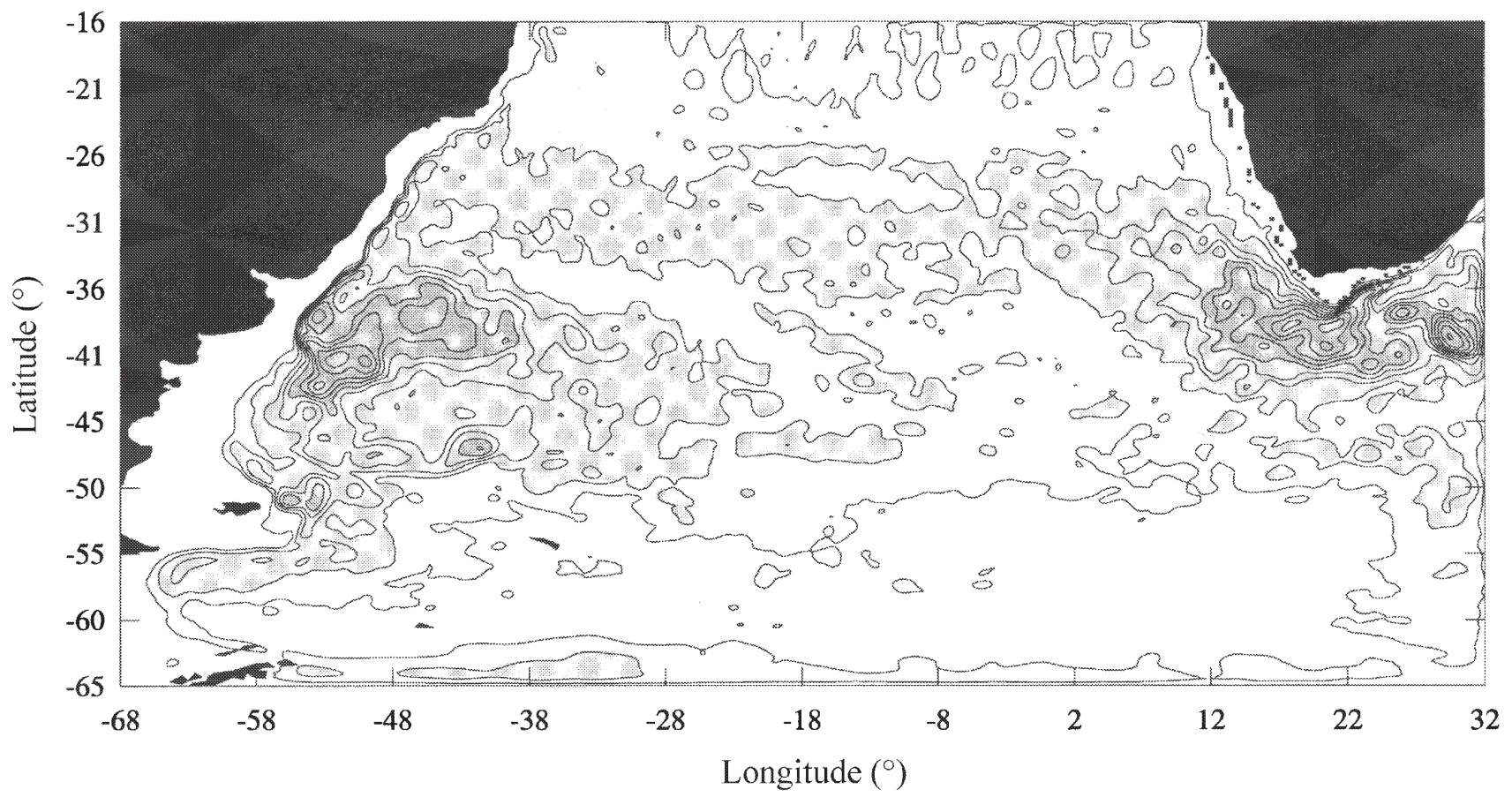

Figure 5. Standard deviation of the annual mean anomalies of the upper-layer circulation. Values larger than $2 / 5 \mathrm{~Sv}$ are coloured in light/dark grey respectively. Contour interval is $1 \mathrm{~Sv}$. 
Current (centred at $38^{\circ} \mathrm{S}-52^{\circ} \mathrm{W}$ ), where the current separates from the coast. A marked interannual variability of the latitude of separation of the Brazil Current from the coast was also observed by Garzoli and Giulivi (1993). They showed that it was forced by anomalous wind patterns south of the Confluence. We stress here that our model is forced by constant winds, so the wind variability is introduced implicitly in the model via the altimeter data. Noticeable interannual variability is also found in the energetic regions of the Malvinas Current and the western part of the Subtropical Front, until it meets the Subantarctic Front near $47^{\circ} \mathrm{S}-10^{\circ} \mathrm{W}$.

In the Agulhas Retroflection area, highest levels of variability correspond to interannual variations in the position of the Retroflection loop, and in the position and strength of the cyclonic meander in the Agulhas Return Current. There is also strong interannual variations in the ring shedding process (number of rings shed per year, dimension and intensity of the eddies). High levels of variability (larger than 3 Sv Rms) extend far from the Retroflection area in the Cape Basin, to Greenwich meridian in the vicinity of the Walvis Ridge. This propagation of the variability to the northwest is related to the drift of eddies in the Benguela Current, and seems to be severely controlled by topography (see also $\$ 4.2$ ).

Finally, we observe from figure 5 a large zonal corridor of variability larger than $2 \mathrm{~Sv} \mathrm{Rms}$, extending throughout the Subtropical Gyre in the $25^{\circ} \mathrm{S}-35^{\circ} \mathrm{S}$ latitudinal band, from the Benguela Current to the coast of Brazil. This corridor is the signature of the eastward propagation of coherent Agulhas eddies across the South Atlantic.

To obtain more information on the variability in this particular latitudinal band, which is the northern limit of the South Atlantic Subtropical Gyre, we have computed the annual mean anomalies of the upper-layer transport averaged over the $27^{\circ} \mathrm{S}-35^{\circ} \mathrm{S}$ latitude band. The resulting curves are presented in figure 6 for each individual year of the five year assimilation experiment. Note that here and in the following, year 1993 in our experiment actually runs from October 1992 (corresponding to the beginning of the T/P altimeter data) to September 1993, and so on for the following years. Positive (anticyclonic) anomalies between 1 and $2 \mathrm{~Sv}$ are observed east of the $0^{\circ}$ longitude, especially in 1993, 1994 and 1997. They correspond to Agulhas eddies drifting in the Benguela Current. West of the $0^{\circ}$ longitude (i.e. approximately west of the Walvis Ridge), the annual anomalies appear more diffuse, with somewhat weaker intensities but broader zonal extent. It is interesting to note that figure 6 suggests a westward displacement of the annual transport anomalies across the Subtropical Gyre. The two peaks observed in 1993 at $14^{\circ} \mathrm{E}$ and $7^{\circ} \mathrm{E}$ seem to have translated westward and to be responsible for the two annual peaks observed in 1994 at $9^{\circ} \mathrm{E}$ and $2^{\circ} \mathrm{E}$ respectively. The information contained in these anomalies (i.e. the eddies) is then likely to participate in the more diffuse positive anomalies observed in 1995 over a large meridional band in the central Subtropical Gyre between $0^{\circ} \mathrm{E}$ and $25^{\circ} \mathrm{W}$, and which appear to propagate westward in 1996 between $15^{\circ} \mathrm{W}$ and $40^{\circ} \mathrm{W}$. Evidence of the impact of several Agulhas eddies on these annual anomalies will be given in the next section.

\subsection{Eddy activity}

Although the model intrinsically exhibits eddy activity through hydrodynamic instabilities, the combination of the assimilation of the altimeter residuals and the non-linear interactions in the model equations enables further development of mesoscale eddies. This mesoscale activity may be subject to interannual variations, which is the subject of the present section. 


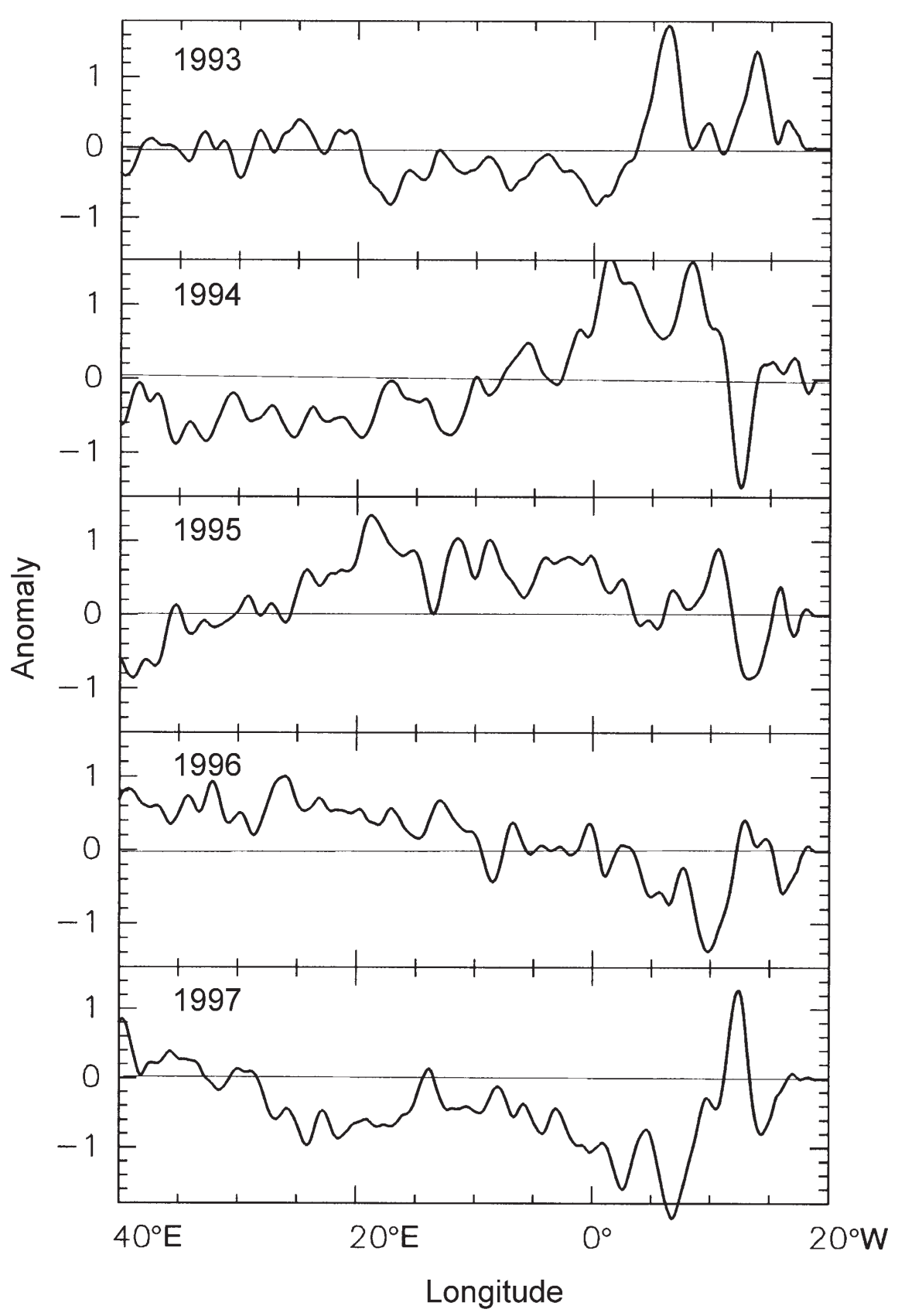

Figure 6. Annual mean anomalies of the upper-layer transport (in Sv) averaged over the $\left(27^{\circ} \mathrm{S}-35^{\circ} \mathrm{S}\right)$ latitudinal band, as a function of the longitude.

To this end, the spatial distribution of the annual mean eddy kinetic energy (EKE) is presented in figure 7 with a time averaged performed at each point over every individual year. The drawings of such EKE maps is still rather noisy, even after a one year time averaging and characterized by steep gradients. This is why we decided to show only two types of EKE patches: one type of patch is defined from the $80 \mathrm{~cm}^{2} \mathrm{~s}^{-2}$ EKE isoline providing for a view of intermediately high levels of EKE and from the $300 \mathrm{~cm}^{2} \mathrm{~s}^{-2}$ EKE isoline providing for a view of high levels of EKE. We think that it is a convenient way to characterize the geography of the EKE variability patterns.

The annual mean eddy-kinetic energy averaged over the domain varies between $85 \mathrm{~cm}^{2} \mathrm{~s}^{-2}$ in 1996 to $90 \mathrm{~cm}^{2} \mathrm{~s}^{-2}$ in 1994 . Most of the eddy activity is concentrated in the Agulhas Retroflection, in the Brazil-Malvinas Confluence and its eastward extension, and in the Antarctic Circumpolar Current west of the Falkland Islands. Maximum surface EKE values reach $1300 \mathrm{~cm}^{2} \mathrm{~s}^{-2}$. It is also apparent that the highest levels of the eddy activity are correlated with areas of weak topography, such as the 

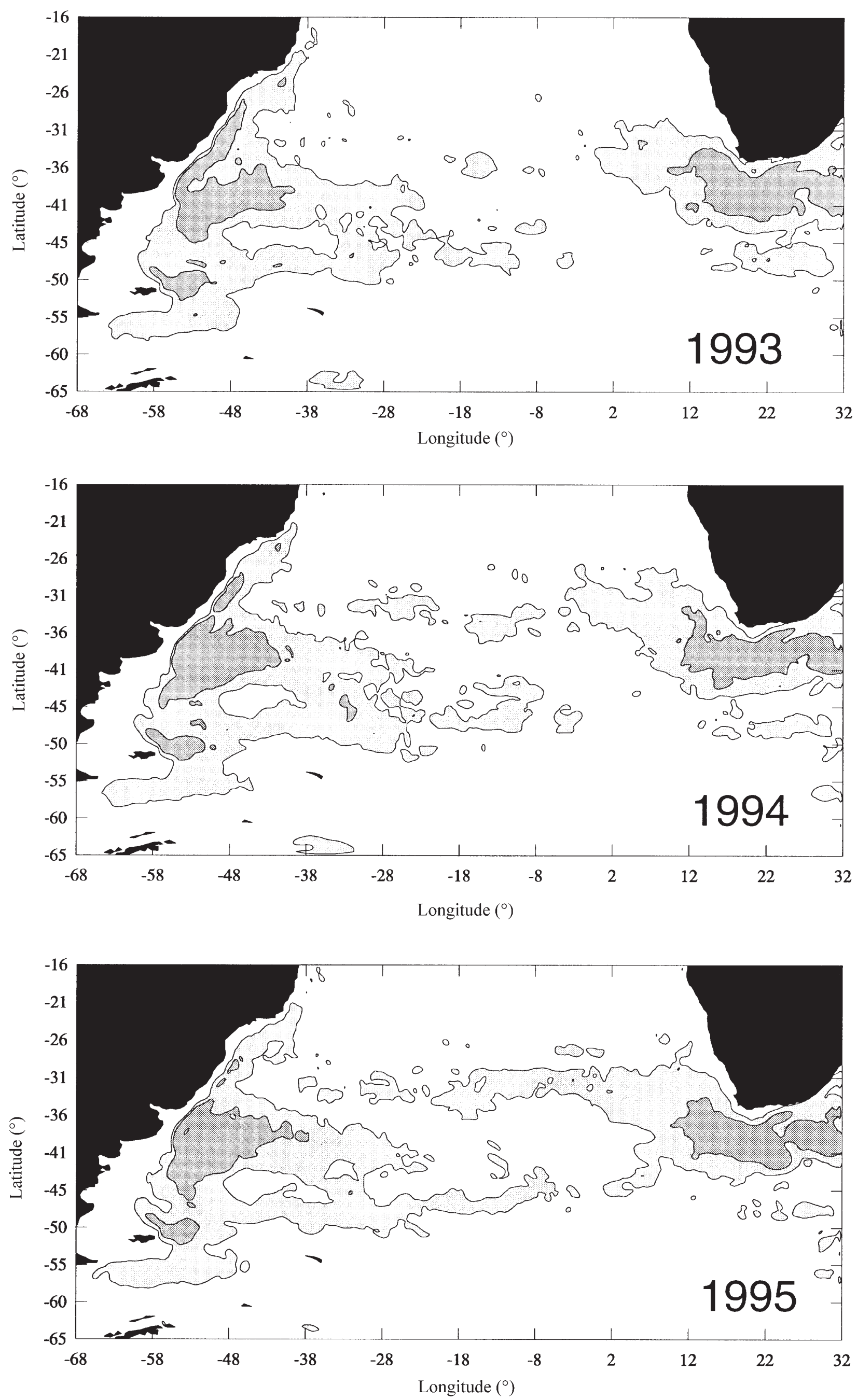

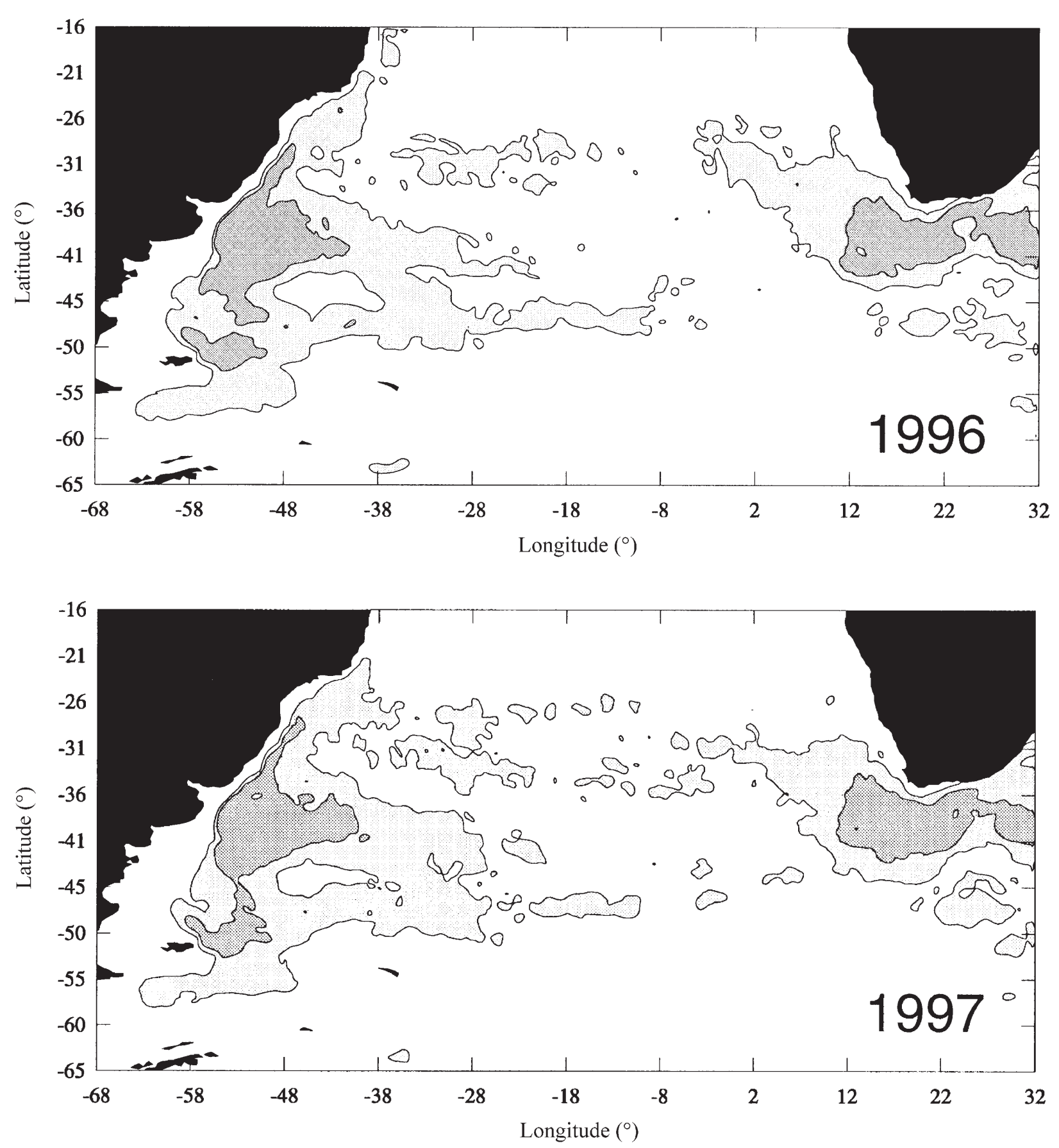

Figure 7. Annual mean eddy-kinetic energy for the 5 years of the experiment. Values larger than $80 / 300 \mathrm{~cm}^{2} \mathrm{~s}^{-2}$ are coloured in light/dark grey.

Cape basin, the Agulhas basin, and the Argentine basin. Conversely, topographic features such as the Walvis Ridge or the Mid-Atlantic Ridge are often associated with weak eddy activity. The Zapiola Anticyclone, located between the Subtropical and the Subpolar front, appears as an elongated pool of minimum eddy variability spreading between $48^{\circ} \mathrm{W}$ and $38^{\circ} \mathrm{W}$ (less than $80 \mathrm{~cm}^{2} \mathrm{~s}^{-2}$ in figure 7), in agreement with the steadiness of the flow as shown in De Miranda et al. (1999). Nevertheless, this anticyclone exhibits interannual variability in its zonal extent.

The eastward extension of the Brazil Current into the South Atlantic Current along $40^{\circ} \mathrm{W}$ is also a region of high eddy variability. This activity is due to the oscillations of the current and to instabilities which generate eddies later drifting eastward in the southern limb of the Subtropical Gyre. Figure 7 shows that the eastward propagation of the eddy activity is subject to interannual variations: the eastern limit of intermediately high $\left(>80 \mathrm{~cm}^{2} \mathrm{~s}^{-2}\right)$ eddy kinetic energy patterns varies zonally between about $26^{\circ} \mathrm{W}$ in 1997 and $22^{\circ} \mathrm{W}$ in 1995. 
The southern branch of the Brazil Current which merges with the retroflected Malvinas Current also extends eastward in the Subantarctic Front along $48^{\circ} \mathrm{W}$. This flow feeds the northern part of the Antarctic Circumpolar Current and is subject to strong oscillations and large meanders, producing a high eddy activity extending eastward from the western boundary between $45^{\circ} \mathrm{S}$ and $50^{\circ} \mathrm{S}$. The eastern propagation of this activity does not seem to go beyond the flank of the Mid-Atlantic Ridge (at about $10-12^{\circ} \mathrm{W}$ ). Interannual variability is observed in the spatial distribution and the zonal extension of this band of eddy activity: the easternmost limit of the eddy kinetic energy level of $80 \mathrm{~cm}^{2} \mathrm{~s}^{-2}$ reaches $5^{\circ} \mathrm{W}$ in 1995 , i.e. far east of the Mid-Atlantic Ridge.

In the eastern basin, the formation of eddies in the Agulhas retroflection region induces high eddy kinetic energy levels (larger than $300 \mathrm{~cm}^{2} \mathrm{~s}^{-1}$ ) as far east as $10^{\circ} \mathrm{E}$ in 1993. Intermediate values between $80 \mathrm{~cm}^{2} \mathrm{~s}^{-2}$ and $300 \mathrm{~cm}^{2} \mathrm{~s}^{-2}$ extend generally up to the Walvis Ridge and correspond to the northwestward drift of the eddies into the Cape basin.

The model Agulhas Return Current is subject to oscillations and is also characterized by high eddy kinetic energy levels. The mean current is steered northward by the Agulhas Plateau, forming a permanent cyclonic meander (i.e. the loop of the Aghulas retreflection current as seen in figure 1). This meander associated with the topographic deflection of the current shows relatively lower eddy activity than in the surrounding, suggesting that the topography has a stabilizing effect on the flow. There is no indication in our simulation that the return current systematically flows south of the Agulhas Plateau in winter, as recently hypothezised by Matano et al. (1998) from an analysis of T/P sea surface anomalies for the period 1993-1996. This cyclonic circulation over the Agulhas Plateau is also a permanent feature of the time mean circulation obtained by Van Leeuwen (1999) in an analysis combining a quasigeostrophic model with $\mathrm{T} / \mathrm{P}$ data using the ensemble smoother (although Van Leeuwen determined the mean over only three months).

In the model, the eddy variability found south of the Agulhas Plateau is due to eddies generated in the retroflection region drifting eastward in the current system associated with the subtropical front. Nevertheless, we observe interannual variations in the position of the meander, with a noticeable northward excursion (up to $37^{\circ} \mathrm{S} / 23^{\circ} \mathrm{E}$ ) in 1996 . Figure 7 also indicates that in the Agulhas Basin, high eddy kinetic energy levels (larger than $80 \mathrm{~cm}^{2} \mathrm{~s}^{-2}$ between $45^{\circ} \mathrm{S}$ and $50^{\circ} \mathrm{S}$ and from $15^{\circ} \mathrm{E}$ to $32^{\circ} \mathrm{E}$ ) take place, probably associated with instabilities of the Subantarctic Front. Strong interannual variations are observed in this region of eddy activity with a large extent of the region in 1993, and a weak one in 1995.

Eddy activity related to the drift of Agulhas eddies is also found in the Subtropical Gyre between $25^{\circ} \mathrm{S}$ and $35^{\circ} \mathrm{S}$ in the form of 'patches' of turbulence characterized by a noticeable interannual variability. In 1994, the regions of kinetic energy larger than $80 \mathrm{~cm}^{2} \mathrm{~s}^{-2}$ progress westward to about $5^{\circ} \mathrm{W}$. In 1995, these patches form a long zonal corridor between $25^{\circ} \mathrm{S}$ and $35^{\circ} \mathrm{S}$, still connected to the Agulhas source and extending westward to $25^{\circ} \mathrm{W}$. In 1996 and 1997, these active areas are detached from the Agulhas source region and are found in the western part of the Subtropical Gyre between $15^{\circ} \mathrm{W}$ and $35^{\circ} \mathrm{W}$. This is consistent with what was suggested previously from figure 6: the drift of Agulhas eddies strongly affects the circulation and its interannual variability in the whole Subtropical Gyre in the $\left(25^{\circ} \mathrm{S}-35^{\circ} \mathrm{S}\right)$ latitudinal band. 


\section{Agulhas eddies}

Indian-Atlantic interocean exchanges of heat, salt and energy are mainly achieved at the Agulhas Retroflection, by the intermittent shedding of enormous (anticyclonic) warm-core rings that penetrate into the South Atlantic. These eddies are of particular interest for the community since they are among the most energetic in the world ocean and they carry heat and salt anomalies far into the Atlantic. They are therefore supposed to affect the basin-scale circulation of the Atlantic, and the global thermohaline overturning circulation. Many studies based on hydrographic observations and/or satellite altimetric data have investigated the creation and characteristics of the Agulhas eddies, together with their role in the interbasin transfer mechanism south of Africa (Lutjeharms and van Ballegooyen 1988, Lutjeharms and Valentine 1997, Gordon and Haxby 1990, Feron et al. 1992, van Ballegooyen et al. 1994, Gründlingh 1995, Byrne et al. 1995, Goni et al. 1997). A review on the subject can be found in De Ruijter et al. (1999).

In this section, we portray several Agulhas eddies observed in our 5-year assimilation experiment. Our aim is not to describe exhaustively the eddy activity during the period, but rather to identify a few characteristical selected eddies and track them during their drift in the South Atlantic. The high spatio-temporal resolution reached in our simulation enable us to track mesoscale eddies quasi-continuously, which is not possible with altimetric data alone (Gründlingh 1995). In addition, the availability of five years of data from $\mathrm{T} / \mathrm{P}$ provide valuable statistics on the characteristics and evolution of the Agulhas eddies during their lifetime.

\subsection{General description}

The ring shedding process occuring in the highly turbulent region of the Retroflection appears very complex. Lutjeharms and van Ballegooyen (1988) studied this process in detail, using satellite infrared imagery and hydrographic data. We have counted about 32 anticyclonic rings shed by the Retroflection loop during the period from October 1992 to September 1997. This gives an average annual rate of shedding of 6.4, in close agreement with other previous estimates, which generally gives an average of 6 rings shed per year (Feron et al. 1992, Byrne et al. 1995, van Ballegooyen et al. 1994, Goni et al. 1997). The frequency of ring shedding occurence is irregular, with an annual rate varying from 5 to 8 . We observed that several rings shed are not entering the South Atlantic (and thus do not participate in the interocean fluxes) but are reabsorbed by the Retroflection loop after a few weeks.

Generally, Agulhas eddies travel with a westward to northwestward direction, preserving their altimetric signature far from the source region throughout their drift in the South Atlantic. An example of instantaneous patterns of circulation anomaly is given in figure 8 in the Agulhas region and the eastern Subtropical gyre. The area is populated with anticyclonic eddies (corresponding to positive sea-level anomalies) with complicated shape and strongly variable diameters (ranging from 200 to $500 \mathrm{~km}$ ). Cyclonic eddies (negative sea-level anomalies) also exist, but they are generally fewer and much weaker than their anticyclonic counterparts. They are mostly due to the substraction of the mean field. Along the path of the Aghulas rings, the MSSH is slightly positive due to the passage of positive anomalies only. When the mean is substracted, negative anomalies appear between the positive rings. Broadly speaking, large and intense Agulhas eddies in the Retroflection area become smaller and weaker as they drift away from their generation region. Indeed, many non-linear 


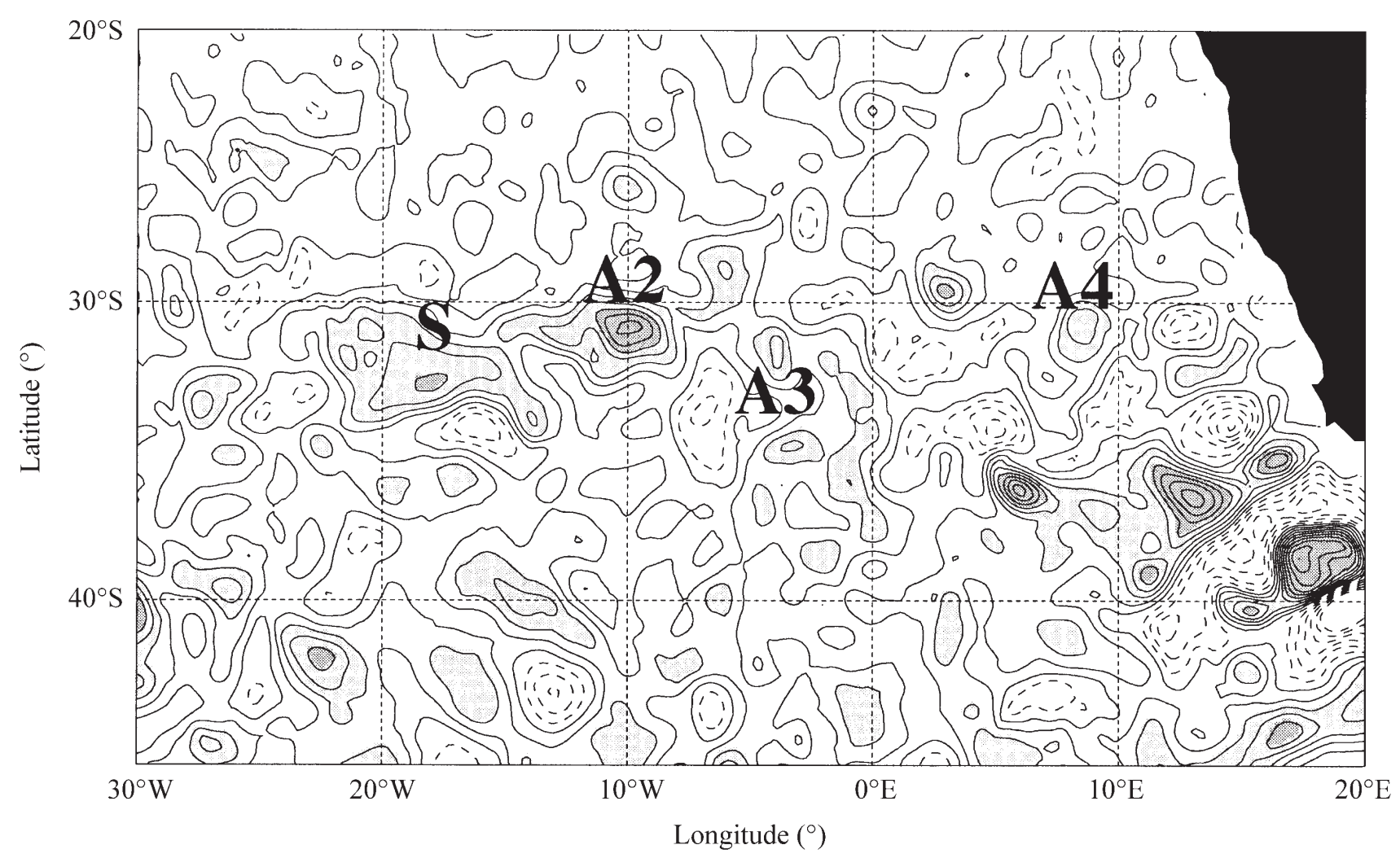

Figure 8. Map of sea-level anomalies in the Retroflection region and the eastern Subtropical Gyre, as produced by the assimilation experiment on 19 March 1995. Contour interval is $5 \mathrm{~cm}$, negative values are dashed. Anomalies larger than $10-20 \mathrm{~cm}$ are coloured in light/dark grey.

processes (such as interactions with the topography or with other eddies) locally complicate this general simple feature (an example will be given in §5.3).

Our experiment revealed a strong influence of the topography on the fate of the Agulhas rings. After formation, a few rings remain in the source region for quite a long time, sometimes for more than one year. This has also been observed by Goni et al. (1997). Such rings seem to be trapped at the Agulhas Ridge (extending between $15^{\circ} \mathrm{E}-40^{\circ} \mathrm{S}$ and $12^{\circ} \mathrm{E}-42^{\circ} \mathrm{S}$ ). They often strongly interact with other rings and with the local steep topography, being eventually dissipated. We also observed a large number of eddies trapped for a long time and sometimes dissipated at the Walvis Ridge. Acting as a barrier, this topographic feature is a critical area for interaction between eddies. For example, an eddy which was stagnating eastward of the Walvis Ridge from the beginning of the observed period was seen to merge with another intense Agulhas eddy (thereafter named A1) in June 1993, and eventually succeeded in crossing the ridge.

No Agulhas eddies were tracked north of $20^{\circ}-25^{\circ} \mathrm{N}$ and south of $40^{\circ} \mathrm{S}$ during the period. This confinement of the eddy paths in the $\left(25^{\circ} \mathrm{S}-40^{\circ} \mathrm{S}\right)$ latitudinal band, between the extension of the Benguela Current to the north and the South Atlantic Subtropical Front to the south, is a common feature to observational studies (Byrne et al. 1995, Gründlingh, 1995). As one goes further north of $25^{\circ} \mathrm{S}$, fewer and fewer Agulhas eddies are observed (see figure 8). They are generally smaller and have weaker altimetric signature than eddies located around $30^{\circ} \mathrm{S}$. Several eddies near $40^{\circ} \mathrm{S}$ and $\left(10^{\circ} \mathrm{E}\right.$ to $\left.20^{\circ} \mathrm{W}\right)$ have been tracked backward in time to check their origin, and none of them has been shown to originate from the Retroflection area. Such eddies might have been generated in the vicinity of the Subtropical Convergence. 


\subsection{Characteristics of few selected eddies}

In terms of interocean transport, every Agulhas eddy which enters the South Atlantic Subtropical Gyre is of interest. The eddies which are dissipated within the Cape Basin see their heat and salt content diffused in the Benguela Current and rapidly transported within this current and its extension into the South Equatorial Current towards the equator. Therefore, they make a direct contribution to the global thermohaline circulation in the Atlantic. The eddies which keep a coherent structure and drift westward in the Subtropical gyre have a different fate, at least for a time, since their heat and salt content are conveyed into the gyre system.

Here, we focus on a few selected eddies which have been spawned at the Retroflection during the 5-year period, have a long life span (of several years), have drifted a long distance away from the formation area and have penetrated the inner regions of the Subtropical gyre.

The global characteristics of the five eddies are summarized in table 1 . The instantaneous position and amplitude in the altimetric signal have been tracked for each eddy at a 32-day interval on our $\frac{10}{6}$ resolution grid. The centre of the eddy is assumed to coincide with the local maximum of sea-level anomaly. We started the tracking process once the rings shed had drifted a small distance away from the immediate source region where the high level of turbulence made the identification difficult. This explains the relatively low values for the initial maximum sea-surface elevation of the eddies (between 38 and $50 \mathrm{~cm}$ ), in comparison with values in the range 40-80 cm encountered in other previous studies (van Ballegooyen et al. 1994, Gründlingh 1995). The distance reported in table 1 is the elapsed distance along the eddy path from the place it was first identified. A straight path between two consecutive positions was here assumed. An eddy-tracking time interval of 16 days, for example, revealed indeed more complicated trajectories (particularly in the vicinity of ridges), and consequently the actual distance covered by the eddies should approximately be 5 to $20 \%$ greater.

Unlike many other Agulhas eddies observed in the experiment, these five eddies preserved their strong altimetric signature throughout their drift in the South Atlantic, and crossed the major topographic obstacles (the Walvis Ridge and the Mid-Atlantic Ridge) without being irremediably dissipated. They moved in a northwestward direction with an overall drift rate varying between 6 and $7 \mathrm{~cm} \mathrm{~s}^{-1}$, which falls within the range of phase speeds reported previously (Byrne et al. 1995, Gründlingh 1995).

The drift tracks of the eddies are presented in figure 9. In the Cape basin, they are steered in a northwestward direction by the background Benguela Current, with

Table 1. Statistics of five selected eddies shed by the Agulhas Current during the period October 1992-September 1997. SLA is the maximum sea-level anomaly at the eddy centre at the start of the eddy-tracking (see text).

\begin{tabular}{lcrlcc}
\hline Eddy & SLA $(\mathrm{cm})$ & $\begin{array}{c}\text { Life span } \\
(\text { month })\end{array}$ & \multicolumn{1}{c}{ Period } & $\begin{array}{c}\text { Distance } \\
(\mathrm{km})\end{array}$ & $\begin{array}{c}\text { Drift rate } \\
\left(\mathrm{cm} \mathrm{s}^{-1}\right)\end{array}$ \\
\hline A1 & 50 & 30 & December 1992-May 1995 & 4628 & 6.2 \\
A2 & 41 & $>52$ & June 1993-September 1997 & 8638 & 6.4 \\
A3 & 43 & 43 & February 1994-August 1997 & 6697 & 5.8 \\
A4 & 38 & 28 & December 1994-March 1997 & 5050 & 7.0 \\
A5 & 40 & $>22$ & January 1996-September 1997 & 3606 & 6.7 \\
\hline
\end{tabular}




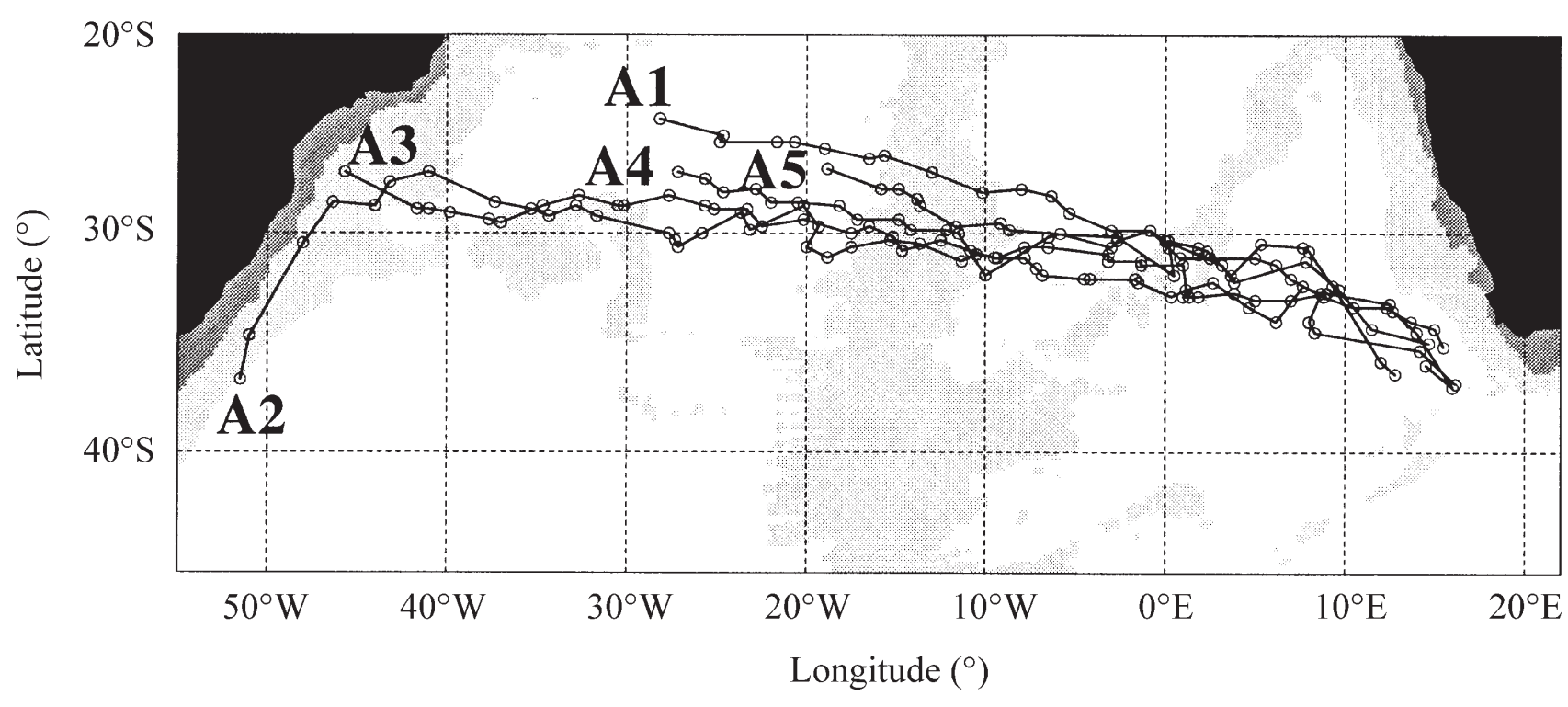

Figure 9. Drift paths of the five selected Agulhas eddies generated during the 5-year experiment. Circles indicate the positions of the eddies at 32-day intervals. Regions where depth of the ocean is less than $3900 \mathrm{~m}$ are coloured in grey.

phase speeds between 5 and $15 \mathrm{~cm} \mathrm{~s}^{1}$. (Note that their intrinsic motion in a quiet environment will also be the same, that is northwestward, see e.g. Beismann et al. (1999). During this journey, they all decay to less than half their initial amplitude, which was also observed in van Ballegooyen et al. (1994).

In the vicinity of the Walvis Ridge, eddies exhibit a strong decrease in their westward phase speed (as can be seen from figure 9), a feature already noticed in other studies (Byrne et al. 1995, Goni et al. 1997). This can be explained theoretically since an anticyclonic eddy in the Southern Hemisphere encountering a meridional ridge develops a northeastward component of translation velocity (Beismann et al. 1999). Each of the five eddies cross the ridge south of $30^{\circ} \mathrm{S}$, and preferentially at gaps in the topographic profile (over depths greater than $2500 \mathrm{~m}$ ). After crossing the Walvis Ridge, the five eddies are steered in a more westward direction and enter the South Atlantic Subtropical Gyre. They all cross the Mid-Atlantic Ridge without being significantly decelerated.

The altimetric signature of eddies A1 and A4 were lost in the Brazil Basin at about $28^{\circ} \mathrm{W}$. Eddy A5 was located near $20^{\circ} \mathrm{W}$ at the end of the experiment (September 1997). Two eddies (A2 and A3) passed the Rio Grande Rise north of $30^{\circ} \mathrm{S}$ and eventually reached the western boundary of the South Atlantic, in the Brazil Current region. Here detecting the eddies is more difficult this far from the source region, their altimetric signal is weak (sometimes less than $10 \mathrm{~cm}$ ) and may be lost in this region of high variability and strong background circulation. For that reason, the signal of eddy $\mathrm{A} 3$ was lost near the coast at $46^{\circ} \mathrm{W}-27^{\circ} \mathrm{S}$, at the northern limit of the Brazil Current. However, eddy A2 was tracked for several months drifting in the Brazil Current. More details about the life history of this eddy is given in the next section.

The influence of the Agulhas eddies on the variability of the Subtropical Gyre may be inferred from figure 10, in terms of the anomalies of the upper layer transport $\psi_{1}^{\prime}$. These anomalies have been meridionally averaged over the $\left(27^{\circ} \mathrm{S}-35^{\circ} \mathrm{S}\right)$ latitudinal band, where most of the eddy paths are confined. On the resulting time-longitude diagram, we have represented the longitudes corresponding to the positions where the five eddies have been tracked. It is quite visible in figure 10 that the eddies 


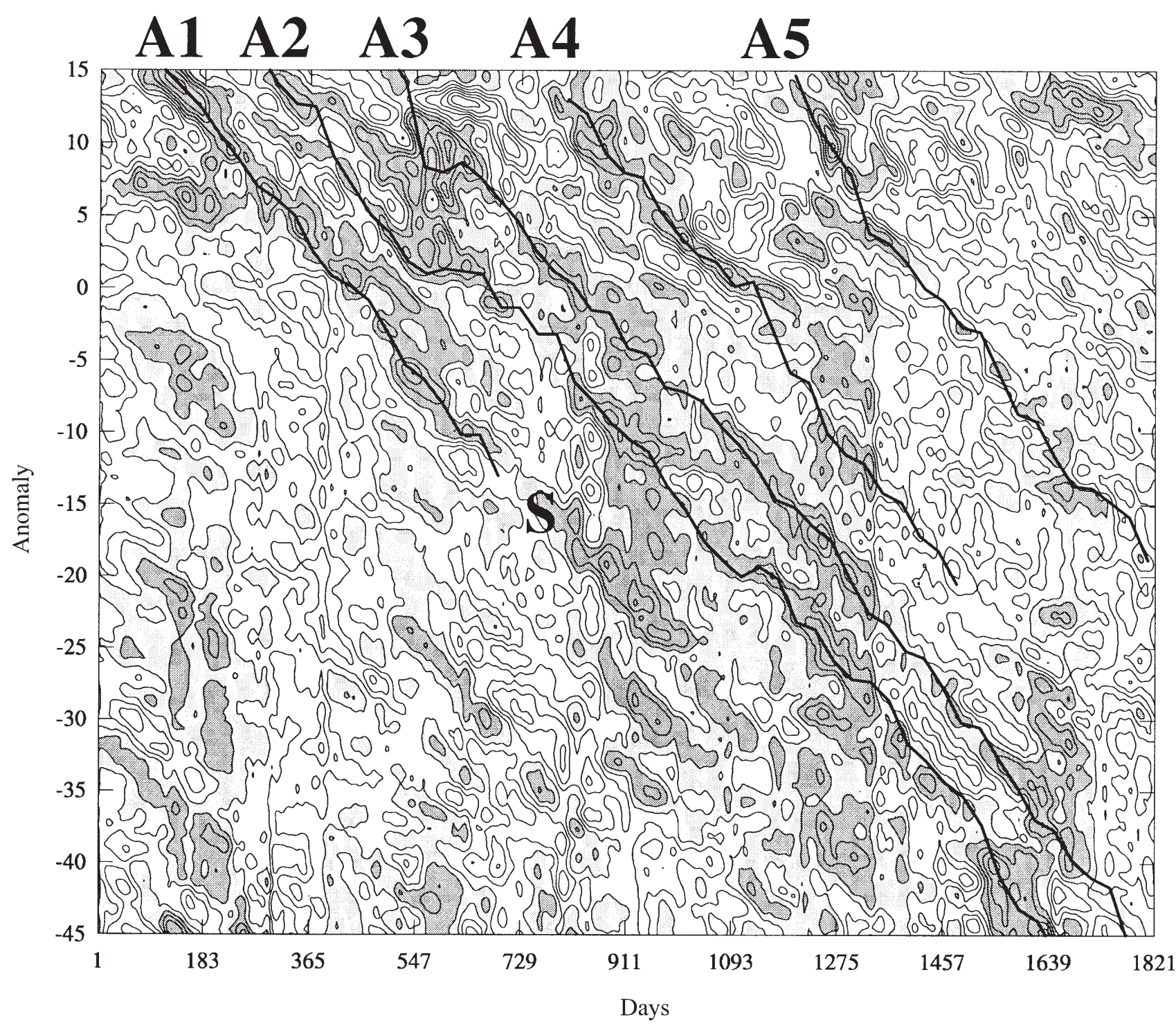

Figure 10. Time-longitude diagram of the upper-layer transport anomalies (in Sv), averaged between $27^{\circ} \mathrm{S}$ and $35^{\circ} \mathrm{S}$. Time unit is in days. Contour interval is $1 \mathrm{~Sv}$. Positive (anticyclonic) anomalies are in light grey, and anomalies larger than $1 \mathrm{~Sv}$ in dark grey. Positions (in longitude) of the five eddies are indicated with thick lines.

identified leave a marked influence on the transport anomalies and their westward propagation throughout the Subtropical Gyre. The positive (anticyclonic) anomalies associated with the Agulhas eddies have amplitude varying between 0.5 and $3 \mathrm{~Sv}$, on average over the $\left(27^{\circ} \mathrm{S}-35^{\circ} \mathrm{S}\right)$ band. It is also interesting to note that apart from the five eddies identified, rather few other structures are found to significantly participate in the variability of the Subtropical Gyre over the 5-year period. This shows the relevance of our selection of eddies and also suggests that a large proportion of the variability in the $\left(27^{\circ} \mathrm{S}-35^{\circ} \mathrm{S}\right)$ latitudinal band is achieved with a small number of Agulhas eddies (more than one eddy per year on average).

From figure 10, it is clear that the annual mean anomalies seen in figure 5 in 1994 and 1995 in the central Subtropical Gyre are related, to a large extent, to the westward propagation of three intense eddies (A2, A3 and A4) in the central South Atlantic (mainly between $0^{\circ} \mathrm{E}$ and $30^{\circ} \mathrm{W}$ ).

We also observe in figure 10 the signature of an anticyclonic structure (referred to as $S$ hereafter), appearing in the $27^{\circ} \mathrm{S}-35^{\circ} \mathrm{S}$ latitude band in October 1994 (approximately at day 750) at about $14^{\circ} \mathrm{W}$ in the continuity of the track of eddy $\mathrm{A} 1$, and propagating northwestward as far as the western boundary current with a 
phase speed comparable with that of the other Agulhas eddies. This structure $S$ has been tracked backward in time from the begining of our experiment (October), when it was a rather small and weak anticyclonic anomaly (with a diameter of about $100-150 \mathrm{~km}$ and altimetric deviation of $12-14 \mathrm{~cm}$ ), located around $8^{\circ} \mathrm{W}-38^{\circ} \mathrm{S}$. Judging from this location (south of most of the Agulhas eddies at this longitude) and from its northward-northwestward initial drift direction, it is surmised that this eddy did not originate from the Agulhas Retroflection but rather from a meander of the Subtropical Front. We then observed a strong enhancement in size and sealevel anomaly of the structure as it passed over the Mid-Atlantic Ridge, suggesting strong interactions with this topography providing negative vorticity fluxes, or a merging with another anticyclonic structure slowed down by the bathymetry. Eddy $S$ is visualized in figure 8 at day 901 (19 March, 1995), after it has crossed the midocean ridge. It is located at about $18^{\circ} \mathrm{W}-33^{\circ} \mathrm{S}$ and appears as a wide pattern, with a rather complicated shape. We also note in figure 8 the presence of the intense eddy $\mathrm{A} 2$ at $10^{\circ} \mathrm{W}-31^{\circ} \mathrm{S}$ still to the east of the Mid-Atlantic Ridge, whereas eddies A3 and $\mathrm{A} 4$ are seen at about $3^{\circ} \mathrm{W}-32^{\circ} \mathrm{S}$ and $8^{\circ} \mathrm{E}-31^{\circ} \mathrm{S}$ respectively. Several anticyclonic eddies of significant strength can also be seen in the Subtropical Front near $40^{\circ} \mathrm{S}$.

\subsection{Life history of eddy $A 2$}

Here we are interested in the fate of eddy A2, which is the most persistent in time and space among the Agulhas eddies tracked during the whole period. The evolution of the deep structure of the eddy will not be investigated here, and we will focus on its characteristics in the upper layers. We note that, according to the date of its first observation, eddy A2 corresponds to the eddy called E2-93 in Goni et al. (1997), which was tracked in the Eastern South Atlantic with T/P data, during the period from November 1992 to December 1995.

The altimetric profiles across eddy A2 are represented in figure 11, along meridional sections at various (but unevenly spaced) stages of its lifetime. The corresponding positions of the eddy along its drift path are indicated in figure 12 . When it reached the Brazil Current, the ring has decayed to nearly one fourth of its initial amplitude, with a sea-level anomaly of about $12 \mathrm{~cm}$. However, the domelike elevation of the sea surface is subject to significant fluctuations in shape and intensity during the eddy propagation in the South Atlantic. Such fluctuations seem to be related, to a large extent, to interactions with the topographic features encountered along its path, namely the Walvis Ridge, the Mid-Atlantic Ridge and the Rio Grande Rise.

Further insight into the eddy evolution may be found in figure 13, which presents time series of the maximum sea-level anomaly at the centre of the eddy, together with the corresponding local topography. We have also estimated the eddy phase speed, $c_{\phi}$, and decay rate distance, $\tau=-c_{\phi}^{-1} d h / d t$ (where $h$ is the eddy height and $t$ is time) between two consecutive positions of the eddy at a 32-day interval. The resulting time series are smoothed by means of a Hanning filter and are presented in figure $13(b)$ and $(c)$. Several points are noteworthy:

1. During its drift in the Benguela Current, eddy A2 decays to less than half its original amplitude: the sea-level anomaly falls from $42 \mathrm{~cm}$ to $18 \mathrm{~cm}$ in less than six months, corresponding to an $e$-folding scale of nearly $1300 \mathrm{~km}$. The horizontal size of the anomaly is also significantly reduced (see figure 11(a) and $(b))$. 


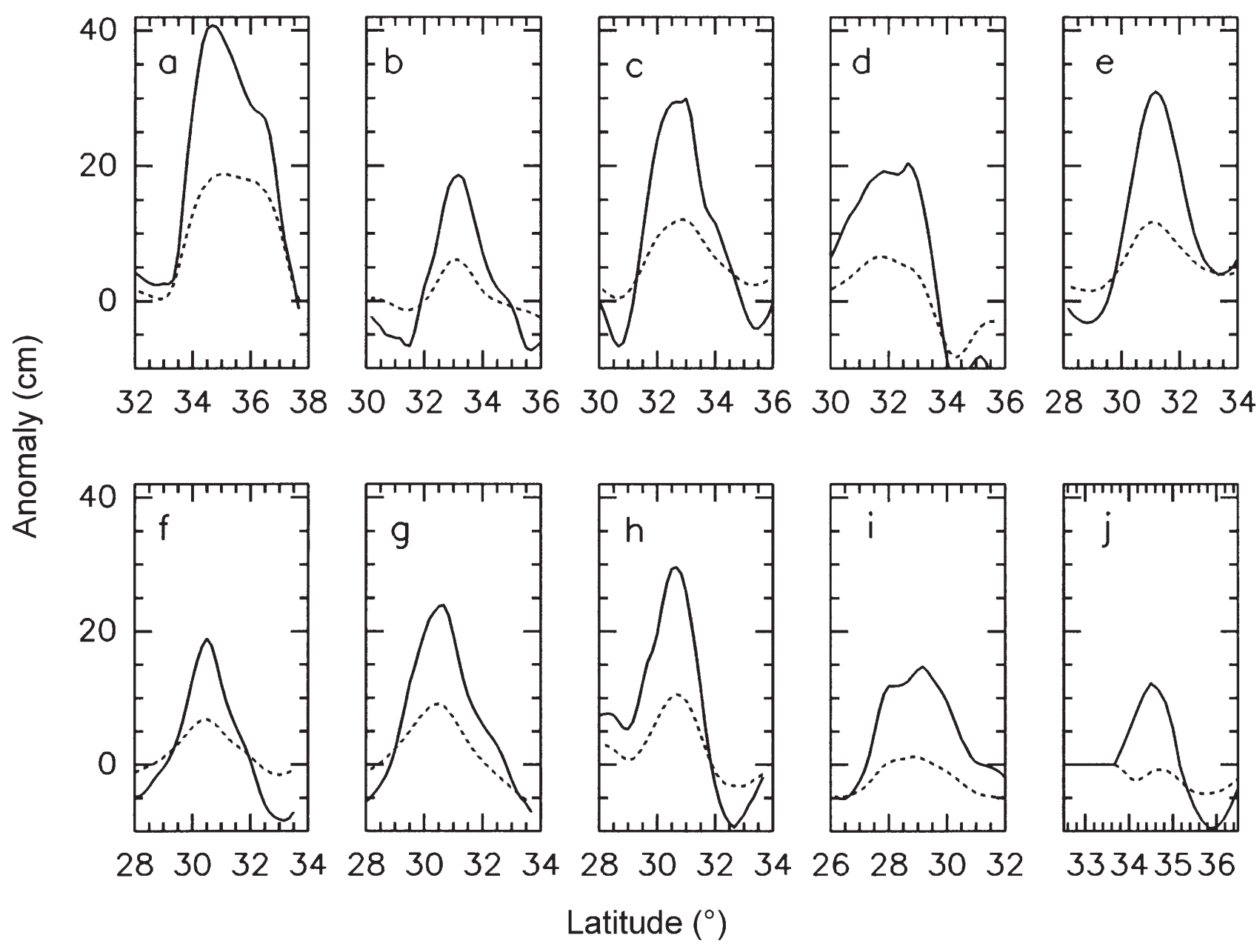

Figure 11. Sea-level anomaly (in $\mathrm{cm}$ ) across eddy A2 (solid line), at the positions indicated on figure 12. (a) 6 August 1993; (b) 12 January 1994; (c) 16 March 1994; (d) 21 June 1994; (e) 4 March 1995; $(f) 8$ June 1995; $(g) 14$ October 1995; $(h) 24$ April 1996; (i) 2 October 1996; $(j) 16$ June 1997. Dotted line corresponds to the equivalent anomaly in layer $3\left(f_{0} / g \cdot \psi_{3}^{\prime}\right)$.

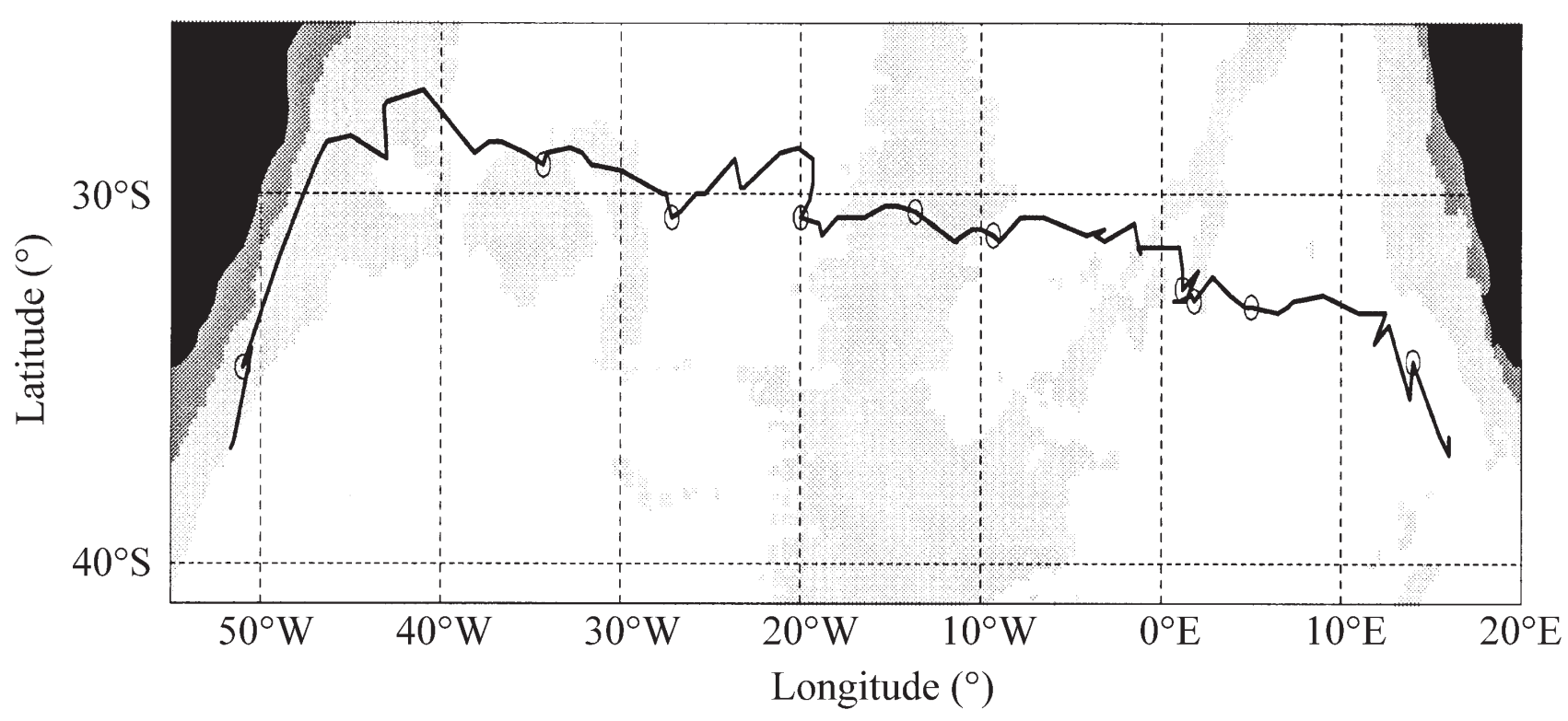

Figure 12. Drift path of eddy A2 as produced with an eddy-tracking time interval of 16 days. Circles indicate the positions of the eddy at the times corresponding to figure 11. Note the more complicated trajectory than with a 32-day interval (see figure 9). 

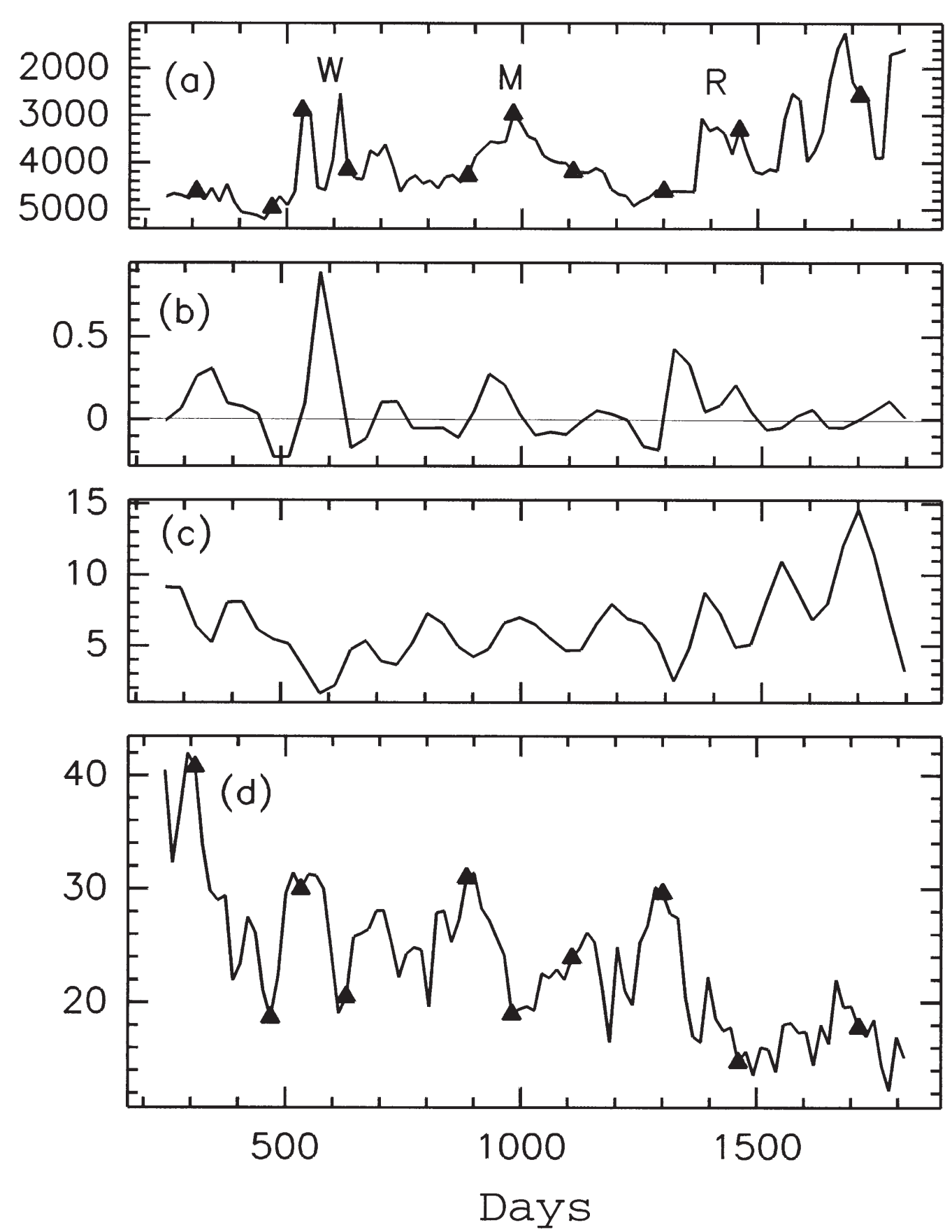

Figure 13. Time series of $(a)$ the bathymetry (in m) over which eddy A2 passes, averaged over $1^{\circ} \times 1^{\circ}$ bins. Topographic ridges are indicated: Walvis Ridge (W), Mid-Atlantic Ridge (M) and Rio Grande Rise (R); (b) the decay rate of eddy height with distance (in $\mathrm{mm} \mathrm{km}^{-1}$ ); (c) the phase speed (in $\mathrm{cm} \mathrm{s}^{-1}$ ); (d) the maximum eddy height (in $\mathrm{cm}$ ). Triangles indicate the positions of the eddy at the times corresponding to figure 11.

2. A noticeable reduction of the phase speed is encountered in the vicinity of steep topography, most strongly marked at the Walvis Ridge. Near this topographic feature, where eddy A2 exhibits a complicated trajectory (see figure 12) and lingers for a long period (of the order of one year), our estimate of the phase speed falls to about $2 \mathrm{~cm} \mathrm{~s}^{-1}$, whereas it is less than $3 \mathrm{~cm} \mathrm{~s}^{-1}$ just before crossing the Rio Grande Rise, a few thousands kilometers farther. This reduction of the phase speed is somewhat less pronounced in the vicinity of the relatively less steep Mid-Atlantic Ridge, where $c_{\phi}$ falls to about $4.5 \mathrm{~cm} \mathrm{~s}^{-1}$.

3. We observe a rapid intensification of the sea-level anomaly just before the eddy centre crosses any of the three ridges. This is especially the case for the Walvis Ridge, where a $14 \mathrm{~cm}$ heightening of the sea surface elevation is obtained in about two months, with a growth rate reaching $1 \mathrm{~mm} \mathrm{~km}^{-1}$ (figures $13(b)$ 
and $(d))$. The increases of sea-level anomaly before eddy A2 crosses the MidAtlantic Ridge and the Rio Grande Rise are $6 \mathrm{~cm}$ and $10 \mathrm{~cm}$ respectively. The numerical study of Kamenkovitch et al. (1995) also revealed a local maximum in eddy centre height (of the order of $10 \mathrm{~cm}$ ) just prior to the time the eddy crosses a topographic ridge. Intensification of the vortex strength of an eddy approaching a ridge has also been evidenced in an idealized study of the Agulhas rings by Beismann et al. (1999). This can be classically explained in terms of conservation of the potential vorticity. However, this feature could not be observed by other previous studies using altimeter data (van Ballegooyen et al. 1994, Gründlingh 1995, Byrne et al. 1995). Nevertheless it cannot be concluded whether the eddies observed in the latter studies actually showed no intensification before crossing the Walvis Ridge or missed this feature because the satellite tracks did not pass close to the core of the eddy at the right time. The loose tracking interval of $\mathrm{T} / \mathrm{P}$ advocates for this latter hypothesis.

4. Just after this intensification, a sudden reduction in the eddy height of about $10 \mathrm{~cm}$ is observed, while the eddy is crossing the ridges. Such a feature has also been noticed in other studies (Kamenkovitch et al. 1995, Byrne et al. 1995). This rapid decline in sea-level anomaly is associated with a peak in decay rates of about $1 \mathrm{~mm} \mathrm{~km}^{-1}$ for the Walvis Ridge and $0.5 \mathrm{~mm} \mathrm{~km}^{-1}$ for the Rio Grande Rise. However, for the Mid-Atlantic Ridge, the reduction in eddy height is not associated with a strong decay rate with distance, since the relatively weak topographic slope does not decelerate the westward propagation of the eddy as much as a steep topography does (Beismann et al. 1999).

\section{Conclusion}

A four layered, eddy resolving ( $\frac{1}{6}^{\circ}$ resolution) quasi-geostrophic model is used to interpolate dynamically in space and time five years of T/P data, from October 1992 to September 1997. Results are analysed in an attempt to provide evidence for a relation between mesoscale eddies and interannual variability of the circulation in the South Atlantic.

The iterative assimilation process which is used to combine the altimeter observations with the model solution allows the 5-year mean circulation to be estimated. In regard to a previous study by Florenchie and Verron (1998), the present solution compares well with that obtained from a 2-year assimilation experiment carried out with the same model, and all major features of the mean surface circulation of the South Atlantic are reproduced. Our present analysis points out an original feature of the mean circulation which is particularly interesting for the validation of the assimilation procedure: the Zapiola Ridge Anticyclone. It is hypothesized that the assimilation of altimeter residuals allows model dynamics to reproduce correctly the eddy-topography interactions which drive this mean flow pattern.

Our analysis of the results in terms of interannual variability provides evidence for an important contribution of the mesoscale eddies generated in the Brazil/ Malvinas Confluence and the Agulhas Retroflection regions.

Year to year variability in these regions appears to be related to the variation in position and strength of the inertial recirculation cell of the Brazil Current, to the variation in position of the Agulhas Current retroflection loop and to the strength of the cyclonic meander of the Agulhas Return Current over the Agulhas Plateau. 
A novel result brought up by the model is the interannual variability observed in the upper layer transport in the $\left(25^{\circ}-35^{\circ}\right)$ latitude band, at the northern limit of the subtropical gyre, and its relation with the westward drift of the Agulhas rings. The $\mathrm{T} / \mathrm{P}$ data suggests that the interannual variability in this region is significant (over $2 \mathrm{~Sv} \mathrm{Rms}$ for a mean flow of the order of $10 \mathrm{~Sv}$ ), and would be mostly related to the life history of the Agulhas rings which survive the interaction with the Walvis Ridge.

Indeed, our analysis also points out the major role of the bottom topography in the general circulation, and in particular that of the Walvis Ridge which has a great influence on the amount of heat and salt carried on by the thermohaline circulation. Of the total number of Agulhas eddies which enter the South Atlantic, a large majority dissipates within the Cape basin, often after they have been blocked by topographic features, such as the seamount chain present at the entrance of the Cape Basin, but more often at the Walvis Ridge. These eddies release their heat and salt into the Benguela Current and thus contribute to the fluxes of these quantities toward the northern hemisphere. The few eddies which manage to cross the Ridge do it at deep passages, sometime after merging with another eddy. But then, eddies can escape the Benguela Current, and they travel within the subtropical gyre.

It is believed that the interactive mechanism between the Aghulas rings and the topographic features surrounding the Cape Basin is a key aspect to increase the northward transport of heat and salt by the thermohaline circulation. The major role of topography on the general circulation is then confirmed as well as the one of the mesoscale eddies.

\section{Acknowledgments}

We would like to acknowledge the contributions of Jean Marc Molines, Eric Blayo and Peter Jan van Leeuwen to this work. Support from this study came from the Centre National d'Etudes spatiales (CNES) and from the Institut Français de Recherche pour l'Exploitation de la Mer (IFREMER) (within the framework of URM 18).

\section{References}

Beismann, J.-O., Kase, R. H., and Lutjerhams, J. R. E., 1999, On the influence of submarine ridges on translation and stability of Agulhas rings. Journal of Geophysical Research, 104, 7897-7906.

Blayo, E., and Le Provost, C., 1993, Performance of the capacitance matrix method for solving Helmoltz type equations in ocean modelling. Journal of Computing Physics, 104, 347-360.

Blayo, E., Verron, J., and Molines, J. M., 1994, Assimilation of TOPEX/POSEIDON altimeter data into a circulation model of the North Atlantic. Journal of Geophysical Research, 99, 24 691-24704.

Byrne, D. A., Gordon, A. L., and Haxby, W. F., 1995, Agulhas eddies: a synoptic view using Geosat ERM data. Journal of Physics and Oceanography, 25, 902-917.

De Miranda, A., Barnier, B., and Dewar, W. K., 1999, On the dynamics of the Zapiola Ridge Anticyclone. Journal of Geophysical Research, 104, 21 137-21 149.

De Ruijter, W. P. M., Biatoch, A., Drijhouft, S. S., Lutjerharms, J. R. E., Matano, R. P., Pichevin, T., Van Leeuwen, P. J., and Weijer, W., 1999, Indian-Atlantic inter-ocean exchange: dynamics, estimation and impact. Journal of Geophysical Research, 104, 20 885-20910.

DEWAR, W. K., 1998, Topography and barotropic transport control by bottom friction. Journal of Marine Research, 56, 295-328. 
Feron, R. C. V., De Ruijter, W. P., and Oskam, D., 1992, Ring shedding in the Agulhas Current system. Journal of Geophysical Research, 97, 9467-9477.

Florenchie, P., and Verron, J., 1998, South Atlantic ocean circulation: simulation experiments with a quasi-geostrophic model and assimilation of Topex/Poseidon and ERS 1 altimeter data. Journal of Geophysical Research, 103, $24737-24758$.

FU, L. L., 1996, The circulation and its variability of the South Atlantic ocean: first results from the TOPEX/POSEIDON mission. In The South Atlantic: Present and past circulation, edited by G. Wefer, W. H. Berger, G. Siedler, and D. J. Webb (Berlin: Springer Verlag), pp. 63-82.

Garzoli, S. L., and Giulivi, C., 1994, What forces the variability of the southwestern Atlantic boundary currents? Deep-Sea Research, 41, 1527-1550.

Goni, G. J., Garzoli, S. L., Roubicek, A. J., Olson, D. B., and Brown, O. B., 1997, Agulhas ring dynamics from Topex/Poseidon satellite altimeter data. Journal of Maritime Research, 55, 861-883.

Gordon, A. L., and Greengrove, C., 1986, Geostrophic circulation of the Brazil-Falkland Confluence. Deep-Sea Research, 33, 573-585.

Gordon, A. L., and Haxby, W. F., 1990, Agulhas eddies invade the South Atlantic: evidence from Geosat altimeter and shipboard conductivity-temperature-depth survey. Journal of Geophysical Research, 95, 7223-7240.

Gornitz, V., 1995, Sea level rise: a review of recent past and near-future trends. Earth Surface Processes and Landforms, 20, 7-20.

Grundilngh, M. L., 1995, Tracking eddies in the southeast Atlantic and southeast Indian oceans with Topex/Poseidon. Journal of Geophysical Research, 100, 24 977-24986.

Hellerman, S., and Rosenstein, M., 1983, Normal monthly wind stress over the world ocean with error estimates. Journal of Physical Oceanography, 13, 1033-1104.

Kamenkovitch, V. M., Leonov, Y. P., Nechaev, D. A., Byrne, A., and Gordon, A. L., 1996, On the influence of bottom topography on the Agulhas eddy. Journal of Physical Oceanography, 8, 892-911.

Lutjeharms, J. R. E., and Valentine, H. R., 1988, Eddies at the Subtropical Convergence south of Africa. Journal of Physical Oceanography, 18, 761-774.

Lutjeharms, J. R. E., and Van Ballegooyen, R. C., 1988, The retroflection of the Agulhas Current. Journal of Physical Oceanography, 23, 79-90.

Matano, R. P., 1993, On the separation of the Brazil Current from the coast. Journal of Physical Oceanography, 23, 79-90.

Matano, R. P., Simionato, C. G., De Ruijter, W. P. M., Van Leeween, P. J., Strub, P. T., Chelton, D.B., and Schlax, M. G., 1998, Seasonal variability in the Agulhas Retroflection region. Geophysical Research Letters, 25, 4361-4364.

Olson, D. B., Podesta, G. P., Evans, R. H., and Brown, O. B., 1988, Temporal variations in the separation of Brazil and Malinas currents. Deep-Sea Research, 35, 1971-1990.

Pearce, A. F., 1977, Some features of the upper $500 \mathrm{~m}$ of the Agulhas Current. Journal of Maritime Research, 35, 731-751.

Pedlosky, J., 1979, Geophysical fluid dynamics (Berlin: Springer Verlag).

Peterson, R. G., and Stramma, L., 1991, Upper-level circulation in the South Atlantic Ocean. Programs of Oceanography, 26, 1-73.

Podesta, G. P., Brown, O. B., and Evans, R. H., 1991 The annual cycle of satellite-derived sea surface temperature in the southwestern Atlantic Ocean. Journal of Climate, 4, 457-467.

Provost, C., Garcia, O., and Garcon, V., 1992, Analysis of satellite sea surface temperature time series in the Brazil-Malvinas Currents confluence region: dominance of the annual and semiannual periods. Journal of Geophysical Research, 97, 17 841-17858.

RAYMOND, W. H., and KuO, H. L., 1984. A radiation boundary condition for multi-dimensional flows. Journal of Quarterly Meteorological Society, 116, 535-551.

REID, J. L., 1989, On the total geostrophic circulation of the South Atlantic Ocean: flow patterns, tracers and transports. Programs of Oceanography, 33, 149-244.

SAunders, P. M., and KIng, B. A., 1995, Bottom currents derived from a shipborne ADCP on the WOCE cruise A11 in the South Atlantic. Journal of Physical Oceanography, 25, 329-347.

Stramma, L., and England, M., 1999, On the water masses and mean circulation of the South Atlantic. Journal of Geophysical Research, 104, 10655-10 678. 
Van Ballegooyen, R. C., Grünlingh, M. L., and Lutjerharms, J. R. E., 1994, Eddy fluxes of heat and salt from the southwest Indian Ocean into the southeast Atlantic Ocean: a case study. Journal of Geophysical Research, 99, 14 053-14070.

VAN LeEweEn, P. J., 1999, The time-mean circulation in the Agulhas region determined with the ensemble smoother. Journal of Geophysical Research, 104, 1393-1404.

Venegas, S. A., Mysack, L. A., and Straub, D. N., 1996, Evidence for interannual and interdecadal climate variability in the South Atlantic. Geophysical Research Letters, 23, 2673-2676.

VERron, J., 1992, Nudging satellite altimeter data into quasi-geostrophic ocean models. Journal of Geophysical Research, 97, 7479-7491.

Verron, J., and Holland, W. R., 1989, Impacts de données d'altimétrie satellitaire sur les simulations numériques des circulations océaniques aux latitudes moyennes. Annals of Geophysics, 7, 31-46.

Witter, D. L., and Gordon, A. L., 1999, Interannual variability of South Atlantic circulation from four years of TOPEX/POSEIDON satellite altimeter observations. Journal of Geophysical Research, 104, 20 927-20948. 